\title{
TREATMENT OF CRITICALLY ILL COVID-19 PATIENTS: PRACTICAL GUIDELINES
}

\section{LEČENJE KRITIČNO OBOLELIH COVID-19 PACIJENATA: PRAKTIČNE SMERNICE}

\author{
Predrag Stevanovićc ${ }^{1,2}$
}

${ }^{1}$ Klinika za anesteziologiju i intenzivno lečenje, KBC "Dr Dragiša Mišović-Dedinje", Beograd, Srbija

${ }^{2}$ Univerzitet u Beogradu, Medicinski fakultet, Beograd, Srbija

Correspondence: predrag.stevanovic@med.bg.ac.rs

Keywords:

COVID-19,

critically ill patients,

intensive care,

circulatory and mechanical support

\section{Abstract}

The coronavirus disease pandemic (2019) has burdened health systems around the world with a large number of severe patients in a short period of time. According to the law of large numbers, a significant number of critically ill COVID-19 patients appear in such conditions which require treatment in the intensive care unit. That percentage of those patients is around $3-5 \%$ in different countries. It is similar in Serbia; however, every rule has its exceptions. KBC "Dr Dragiša Mišović-Dedinje“ in Belgrade has been determined to take care of the most difficult COVID-19 patients since the beginning of the epidemic due to its space, organizational and personnel possibilities. Out of the total number of patients treated in KBC "Dr Dragiša Mišović-Dedinje", about $25 \%$ of patients were treated in the intensive care unit for the above mentioned reasons.

Guided by valid treatment protocols, Anesthesiology and Intensive Care clinic of the KBC "Dr Dragiša Mišović-Dedinje” has developed its own work protocols for rapid diagnosis, isolation and clinical management of such difficult patients. These protocols are important not only for the treatment of the most severe COVID-19 patients, but also for the best utilization of hospital resources, as well as for the prevention of the spread of the infection to the medical staff. Extensive experience in the treatment of critically ill patients was gained from the entire engagement during the epidemic, experienced doctors, anesthesiologists-intensivists with great knowledge in the field of work in the intensive care unit, but also managers of clinics and institutions, who can share their experience with health care policy makers. It is clear that in the future, the capacities and organization of work in the field of intensive care medicine should be redefined, as well as health workers should be trained to work in the most demanding field of medicine. Expert experience in the form of practical guidelines, derived from over fourteen months of continuous work in the red zone of COVID-19, where they fought for every breath of the patient, in this review are translated into simplified guidelines for orientation of those who find themselves in a similar situation. 


\section{Sažetak}

Pandemija uzrokovana korona virusom (engl. Coronavirus disease 2019) opteretila je zdravstvene sisteme širom sveta velikim brojem kritično obolelih pacijenata u kratkom vremenskom roku. Po zakonu velikih brojeva, u takvim uslovima se javlja i značajan broj kritično obolelih COVID-19 pacijenata, koji zahtevaju lečenje u jedinici intenzivnog lečenja. Taj procenat se kreće oko 3 - 5\% u različitim zemljama. I u Srbiji je slično. Ipak, svako pravilo ima i izuzetke. KBC „Dr Dragiša Mišović-Dedinje“ u Beogradu je zbog prostornih, organizacionih i kadrovskih mogućnosti od početka epidemije opredeljen za zbrinjavanje najtežih COVID-19 pacijenata. Od ukupno lečenih u KBC „Dr Dragiša Mišović-Dedinje“, iz prethodnih razloga, oko $25 \%$ pacijenata je lečeno u jedinici za intenzivno lečenje.

Rukovodeći se važećim protokolima lečenja, Klinika za anesteziologiju i intenzivno lečenje KBC „Dr Dragiša Mišović-Dedinje“ razvila je i sopstvene protokole rada za brzu dijagnostiku, izolaciju i kliničko vođenje tako teških pacijenata. Ti protokoli su važni, ne samo za lečenje najtežih COVID-19 pacijenata, već i za najbolje iskorišćenje bolničkih resursa, kao i za prevenciju širenja infekcije na zdravstveno osoblje.

Iz celokupnog angažmana tokom epidemije stečena su ogromna iskustva u lečenju kritično obolelih pacijenata, stasali su iskusni lekari, anesteziolozi-intenzivisti sa velikim znanjem u oblasti rada u jedinici intenzivnog lečenja, ali i upravnici klinika i ustanove,

Ključne reči:

\section{COVID-19,}

kritično oboleli pacijenti, intenzivno lečenje, cirkulatorna i mehanička podrška koji mogu svoje iskustvo preneti kreatorima politike u oblasti organizacije zdravstva. Jasno je da u budućnosti treba redefinisati kapacitete i organizaciju rada u oblasti intenzivne medicine, kao i obučiti zdravstvene radnike za rad u ovoj najzahtevnijoj oblasti medicine. Iskustva tokom 14 ili više meseci rada u „crvenoj zoni kovida“ pretočena su u pojednostavljene praktične smernice, koje mogu poslužiti svima koji se u budućnosti nađu u sličnim kliničkim situacijama.
Uvod

Koronavirusna bolest 2019 (engl. Coronavirus disease 2019, COVID-19) uzrokovana je virusom SARSCoV-2 (engl. Severe acute respiratory syndrome coronavirus 2). Pandemijskih je razmera, sa izuzetno velikim brojem zaraženih u svetu i sa značajnim mortalitetom. Od ukupno zaraženih pacijenata, procenat onih sa najtežom kliničkom slikom, kritično obolelih, koji zahtevaju lečenje u jedinici intenzivnog lečenja (JIL) po podacima iz literature iznosi oko 3\% (1). KBC „Dr Dragiša Mišović-Dedinje“, kao prva bolnica u našoj zemlji koja je ušla u COVID režim rada posle Infektivne klinike KCS, tokom epidemije je sve vreme namenjena zbrinjavanju najtežih pacijenata iz cele Srbije, tako da je procenat onih koji su morali biti lečeni u JIL iznosio preko 25\%. Tokom lečenja kritično obolelih COVID-19 pacijenata korišćene su terapijske smernice predložene od strane Svetske zdravstvene organizacije, Američkog i Evropskog udruženja anesteziologa i intenzivista, kao i protokoli kriznog štaba Republike Srbije.

Nema smernica koji mogu da zadovolje potrebe svih pacijenata. Poštujući predložene postulate pomenutih udruženja, formirali smo svoje protokole lečenja i s vremenom ih modifikovali na osnovu novih naučnih informacija koje su svakodnevno pristizale.

\section{Šta znamo o SARS-CoV-2 virusu?}

Za razumevanje terapijskih modaliteta, ali i onih koji se koriste u prevenciji, neophodno je poznavanje patofizioloških mehanizama i načina delovanja ovog virusa. Fligeove kapljice predstavljaju glavni put transmisije ovog virusa (2). SARS-CoV-2 genom, dužine oko 30 nukleotida, sastoji se od jednolančane RNK koja je inkapsulirana unutar membranske ovojnice. Virus se sastoji od 15 nestrukturnih i 4 strukturna proteina ("spike" glikoprotein, membranski protein, "envelope" protein i nukleokapsid) $(3,4,5)$. "Spike" (šiljak) glikoproteini, koji se nalaze na površini membranske ovojnice, virusu daju izgled krune, odakle i potiče naziv koronavirus (lat. corona, kruna). Za replikaciju virusa neophodno je prisustvo ćelije domaćina. Virus se preko "spike" glikoproteina vezuje za receptor angiotenzin konvertujućeg enzima-2 (ACE2) koji se nalazi na membrani ćelije domaćina i principom endocitoze ulazi u ćeliju domaćina (slika 1). Ovaj proces je posredovan transmembranskom serinskom proteazom (TMPRSS2). Receptori ACE2 se nalaze na površini ćelija brojnih organa, npr. srca, jetre, bubrega, testisa, pluća, gastrointestinalnog trakta i dr. pri čemu se $83 \%$ ovih receptora nalazi na površini pneumocita tipa II (6). Nakon ulaska u ćeliju domaćina, virus oslobađa jednolančanu RNK, koja se pomoću ribozoma domaćina prevodi u virusne poliproteine od kojih pomoću virusnih proteinaza nastaju gore pomenuti efektorni proteini. Genom se replikuje, a transkripcijom i translacijom nastaju 4 esencijalna strukturna proteina. Ovako nastala „ćerka" virusa se procesom egzocitoze otpušta iz ćelije domaćina, napada susednu ćeliju i proces se ponavlja (7). Na ovaj način se virus širi od nosnica do alveola (8).

Postoji nekoliko patofizioloških mehanizama koji se prepliću kod infekcije COVID-19, uključujući koagulopatiju, endotelnu disfunkciju i prekomerno oslobađanje proinflamatornih citokina. Endotelna disfunkcija dovodi do prekomerne aktivacije trombina i inhibira fibrinolizu, dovodeći time do nastanka hiperkoagulabilnog stanja (9). 
Narušava se vaskularni integritet alveolokapilarne membrane, povećava permeabilnost i posledično nastaje plućni edem. Aktiviraju se putevi diseminovane intravaskularne koagulopatije (DIK), nastaju plućna ishemija, hipoksija i hipoksemija, koje se produbljuju u progresivno oštećenje pluća (10). Virus preko oštećene alveolokapilarne membrane ulazi u krvotok i stiže do ostalih organa i organskih sistema, gde uzrokuje srčane i neurološke poremećaje, miokarditis, infarkt miokarda, srčanu insfucijenciju, moždana krvarenja, ishemijski moždani udar, komu i potencijalno, smrt domaćina (11).

U osnovi patofiziološkog mehanizma je vezivanje virusa za ACE2 receptor na površini domaćina, koje inicira lokalizovanu inflamaciju, aktivaciju endotela, oštećenje tkiva i oslobađanje citokina sa posledičnom citokinskom olujom kod najtežih slučajeva. Ovo dovodi do povećane vaskularne permeabilnosti, što je osnova nastanka hipotenzije i oštećenja pluća različitog stepena (12). Kod teških formi COVID-19 infekcije dolazi do aktivacije koagulacione kaskade sa potencijalnim nastankom tromboze i DIK-a. Kao rezultat DIK-a i tromboze malih, ali i većih krvnih sudova, nastaje ishemija plućnog tkiva, koja pokreće angiogenezu i potencijalnu hiperplaziju epitelnih ćelija (13). Tuven (Teuwen) je u svom istraživanju predstavio više mogućih mehanizama nastanka povećane vaskularne permeabilnosti: a) direktno delovanje virusa na epitelne ćelije, koje će dovesti do generalizovanog endotelitisa sa disfunkcijom i lizom epitelnih ćelija; b) vezivanjem za ACE2 receptore smanjuje se njihova aktivnost $\mathrm{i}$ indirektno potencira aktivacija kalikrein-bradikinin puta, što dovodi do povećane vaskularne permeabilnosti; c) produkcija histotoksičnih medijatora posredovana aktivacijom neutrofila u plućnom parenhimu; d) aktivacija imunskih ćelija, citokina i vazoaktivnih medijatora koji će povećati kontraktilnost epitelnih ćelija i povećati otvor međuendotelnih spojeva na alveolokapilarnoj membrani; e) aktivacija glukuronidaze posredstvom interleukina $1 \beta$ i faktora nekroze tumora (TNF), koja dovodi do oštećenja i razgradnje glikokaliksa (10).

Teška klinička slika, koja se karakteriše bilateralnom pneumonijom i akutnim respiratornim distres sindromom (ARDS), posredovana je ekstremno jakim odgovorom imunskog sistema, što dovodi do abnormalnog oslobađanja proinflamatornih citokina (IL-6, IL-1, IL-2, IL-10, TNF- $\alpha$, interferon- $\gamma$ ) i drugih proinflamatornih ćelija, kao npr. granulocita i makrofaga (makrofagni aktivacioni sindrom, MAS), što je nazvano citokinskom olujom. Pored ovog, dolazi i do oslobađanja antiinflamatornih citokina npr. interleukina 4 i 10 (IL-4 i IL-10), što je takođe dovedeno u vezu sa razvojem teške kliničke slike (14). Citokinska

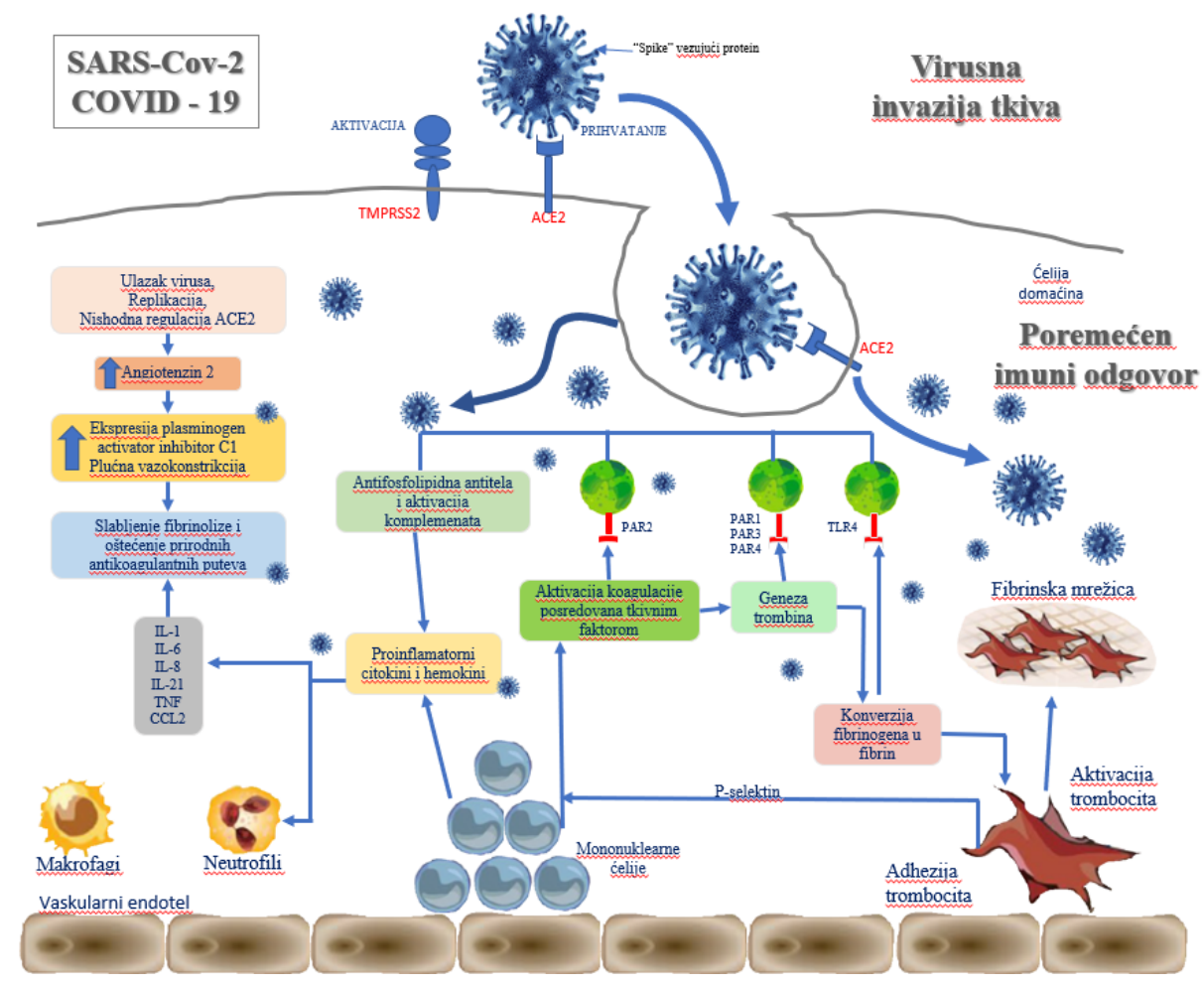

Slika 1. Patofiziologija infekcije SARS-CoV-2. SARS-CoV-2 se preko svog površinskog šiljastog proteina vezuje za humani ACE2 receptor nakon aktivacije šiljastog proteina pomoću TMPRSS2. Ovo dovodi do smanjene regulacije ACE2 i povećanja nivoa angiotenzina II i posledično, povećanja ekspresije plazminogen inhibitora aktivatora C-1 i smanjenja fibrinolize. Bolest koju izaziva povezana je sa povećanjem upalnih citokina i poremećajem koagulacije, sa predispozicijom za stvaranje tromba. Mononuklearne ćelije stupaju u interakciju sa aktiviranim trombocitima i koagulacionom kaskadom, što aktivira inflamatorne ćelije vezivanjem trombina i tkivnog faktora sa specifičnim receptorima aktiviranim proteazom i vezivanjem fibrina za “Toll like-4" receptor. Aktivacija upalnih ćelija dovodi do oslobađanja proinflamatornih citokina, što dovodi do oštećenja prirodnih puteva koagulacije i zaustavljanja fibrinolize. Ovo stanje hiperupale i hiperkoagulabilnosti dovodi do disfunkcije više organa, a najčešće su pogađeni pluća, srce i bubrezi. Angiotenzin-konvertujući enzim-2 - ACE2; interleukin - IL; receptor aktiviran proteazom - PAR; transmembranska serin proteaza - TMPRSS2, faktor nekroze tumora - TNF $\alpha$. 
oluja dovodi do funkcionalnog „kolapsa“ T-ćelija imunskog sistema, difuznog alveolarnog oštećenja, ARDS-a i potencijalno smrti pacijenta (15). Poremećaj imunskog sistema, nastao u citokinskoj oluji, dovodi do oštećenja endotela i aktivacije koagulacije sa nastankom mikro/ makrotromboza. Aktivacija ACE2 receptora na površini trombocita dovodi do masivne agregacije trombocita karakteristične za COVID-19. Trombotska mikroangiopatija predominantno zahvata plućnu i cerebralnu cirkulaciju.

COVID-19 se javlja u čitavom spektru kliničkih oblika, od kojih najveći broj pacijenata čak i ne zahteva hospitalizaciju (Protokol za lečenje pacijenata sa COVID-19 - Krizni štab Republike Srbije).

OBLIK 1: Asimptomatska ili vrlo blaga klinička slika. Kućno lečenje uz kontrole i nadzor kovid ambulanti. Osobe su bez znakova bolesti, a sa pozitivnim nazofaringealnim brisom (PCR na COVID-19) ili bolesnici bez komorbiditeta i sa blagim oblikom infekcije (hospitalizovani pacijenti sa $\mathrm{SpO}_{2}$ (saturacija hemoglobina kiseonikom u perifernoj krvi) > 94\% i bez radioloških znakova pneumonije).

OBLIK 2: Blaga klinička slika. Kovid centri - odeljenje opšteg tipa, opšte bolnice - izolacione jedinice, mere opšteg, pojačanog nadzora, više puta dnevno praćenje temperature, $\mathrm{SpO}_{2}$ i frekvencije disanja. To su bolesnici bez komorbiditeta i sa blagim oblikom infekcije (hospitalizovani pacijenti sa $\mathrm{SpO}_{2}>94 \%$ sa radiološkim znacima pneumonije, sa ili bez znakova hipoksije na prijemu).

OBLIK 3: Umereno teška klinička slika. Kovid centri - poluintenzivne nege. Opšte bolnice - izolacione jedinice sa stalnim nadzorom intenziviste ili anesteziologa ili infektologa ili interniste - nadzor svakog sata i češće. Teška hipoksija, febrilnost, multiple opacifikacije na radiografiji (RTG) pluća (ili specifične CT promene), pacijent je dobro odreagovao na oksigenu terapiju $\left(\mathrm{SpO}_{2}\right.$ $>90 \%$ nakon primene kiseonika na nazalni kateter ili masku sa protokom od $10-15 \mathrm{~L} / \mathrm{min}$ u trajanju od sat vremena). U slučaju izostanka terapijskog efekta ili daljeg pogoršanja - transfer u kovid centar.

OBLIK 4 i 5: Teška i vrlo teška klinička slika. Kovid centri - intenzivna nega. Početak ili razvoj ARDS-a.

Zbog brojnosti zaraženih virusom SARS-CoV-2, po pravilu velikih brojeva, značajan broj pacijenata zahteva hospitalizaciju i time uveliko opterećuje bolničke resurse i zdravstveni sistem u celini. Da bi se mogućnosti zdravstvenog sistema u prenapregnutim uslovima maksimalno iskoristile potrebno je upoznati bolest i uspostaviti adekvatnu trijažu shodno težini kliničke slike. Ne zahteva svaki klinički oblik hospitalizovanih pacijenata isto angažovanje resursa $i$ isti nivo lečenja i nege.

Radi adekvatne trijaže na prijemu pacijenata $u$ bolnicu radi se osnovna dijagnostika (krvna slika sa obaveznom leukocitarnom formulom, set biohemijskih analiza, inicijalna radiografija pluća i srca ili kompjuterizovana tomografija grudnog koša - zavisno od stanja u kom se pacijent $\mathrm{u}$ tom trenutku nalazi).
Klinička slika

Klinički znaci i simptomi COVID-19 su nespecifični. Najčešće počinju povišenom telesnom temperaturom, malaksalošću, umorom, suvim kašljem, mialgijom, suvoćom i bolom u grlu, glavoboljom, mučninom, povraćanjem, dijarejom, gubitkom čula mirisa i ukusa. Ukoliko dođe do razvoja teške kliničke slike, ovi simptomi mogu da progrediraju do osećaja kratkog daha, gubitka apetita, dispneje, hipotenzije, hipoksije, hipoksemije, hiperpireksije, poremećaja stanja svesti i kome.

Kritično oboleli COVID-19 pacijenti se predominantno primaju u JIL (jedinica intenzivnog lečenja), usled razvoja respiratorne insuficijencije. Klinički nalaz na plućima se kreće od jednostrane ili obostrane pneumonije, atelektaza, pneumotoraksa ili pneumomedijastinuma sa supkutanim emfizemom ili bez njega, a u najtežem obliku se javlja ARDS. Kasnije se sve komplikuje superinfekcijom i sepsom.

\section{Laboratorijski nalazi}

Pošto COVID-19, pored pluća, napada i druge organske sisteme, kod pacijenata sa umerenom i teškom kliničkom slikom uočavaju se brojne abnormalnosti u laboratorijskim nalazima. Nastanak početne koagulopatije je karakterisan povišenim vrednostima D-dimera (16). Oštećenje srčanog mišića ovim virusom dovodi do povišenja vrednosti troponina, pro-BNP i kreatin-kinaze. Usled nastanka akutne bubrežne insuficijencije mogu se uočiti povišene vrednosti uree i kreatinina, kao što usled oštećenja jetre dolazi do porasta aspartat (AST) i alanin (ALT) aminotransferaze (17). U krvnoj slici je karakterističan nalaz leukopenije sa limfopenijom i trombocitopenijom. Uočava se smanjen procenat monocita, eozinofila i bazofila kod pacijenata sa blagom i umereno teškom kliničkom slikom (18). Neutrofilija i povećan odnos neutrofila i limfocita karakteristični su za tešku kliničku sliku i nepovoljan klinički ishod bolesti.

\section{Dijagnostika}

Dijagnoza bolesti zavisi od dva aspekta: a) patogena koji uzrokuju bolest, njihovih komponenti i stadijuma životnog ciklusa ovih patogena i b) odgovora domaćina, uključujući sintezu mikro/makrometabolita. Za potrebe skrininga, kao jednog od ključnih koraka u borbi protiv COVID-19, zlatni standard je metoda polimerazne lančane reakcije u realnom vremenu (RT-PCR), naročito kod asimptomatskih pacijenata i onih sa blagom kliničkom slikom jer su pacijenti infektivni oko 3 dana pre i do 6 dana nakon početka prvih simptoma. Kao uzorci se najčešće koriste nazofaringealni i orofaringealni bris, ali i bris konjunktive (19). Identifikacija asimptomatskih bolesnika ostaje glavni problem u sprečavanju širenja COVID-19. U idealnim uslovima, za pristizanje rezultata ovog testa potrebno je 2 do 5 sati, mada u praksi to često iznosi i do $24 \mathrm{~h}$ zbog velikog broja testiranih na dnevnom nivou. Senzitivnost 
ovog testa na samom početku bolesti iznosi oko $60 \%$, dok u kasnijem toku bolesti može porasti na $80 \%$, što govori u prilog velikom broju lažno negativnih rezultata. Često se uočavaju pacijenti koji imaju karakterističnu kliničku sliku, pozitivnu anamnezu kontakta sa zaraženim osobama, tipičan radiološki i laboratorijski nalaz za COVID-19, ali je PCR test negativan. Kasnije je razvijen brzi antigenski test, čiji su rezultati dostupni nakon samo 5 minuta. Mehanizam ovog testa se zasniva na izotermnoj amplifikaciji nukleinske kiseline, nakon čega se posebnim instrumentom prati RNK zavisna polimeraza ovog virusa (20). U dijagnostikovanju ove bolesti koriste se i serološki testovi. Iako je primena seroloških testova bila upitna zbog unakrsne reaktivnosti antitela sa drugim virusima iz familije koronavirusa, njihov veliki značaj je pokazan u proceni stadijuma i progresije bolesti. Ne samo da su ovi testovi značajni u skriningu pacijenata i zdravstvenih radnika već pokazuju i njihov imunološki status $(20,21)$. Uspešnost ovih testova u dijagnostikovanju COVID-19 je povećana u kombinaciji sa radiološkim snimcima pluća i grudnog koša (kompjuterizovana tomografija - CT i rendgensko snimanje).

Kompjuterizovana tomografija se pokazala značajnijom od standardne radiografije pluća jer je efikasnije $\mathrm{i}$ preciznije definisala obolele, kao i okvirni stadijum bolesti u kome se pacijent nalazi. Kompjuterizovana tomografija grudnog koša se može koristiti i kao samostalna rana dijagnostička metoda u uslovima manjka testova (22). Karakterističan nalaz CT grudnog koša pacijenata obolelih od COVID-19 sadrži prisustvo konsolidacija plućnog parenhima, linearne neprozirnosti, prisustvo opacifikacija i „mlečnog stakla“, kao i takozvani “crazy-paving” (popločavanje) i ovaj nalaz se skoruje na osnovu zahvaćenosti plućnog parenhima ovim promenama (engl. Severity Score 0 - 25, pri čemu ocena 25 predstavlja 100\% plućnog parenhima zahvaćenog gore navedenim promenama) (23). Na rendgenskom snimku pluća se kod ovih pacijenata uočava prisustvo konsolidacija, ali sa manjim stepenom preciznosti u poređenju sa CT-om (24).

\section{Terapijski pristupi}

Do današnjeg dana jedinstven efikasan lek protiv COVID-19 ne postoji. Ključno u tretmanu ovih pacijenata je rano postavljanje dijagnoze, izolacija i mere prevencije (zaštitne maske, higijena ruku, socijalna distanca). Terapijski pristupi se zasnivaju na suportivnoj terapiji, respiratornoj i nutritivnoj podršci. Klinički tok bolesti je podeljen na 4 perioda: period inkubacije, simptomatsku fazu, ranu i kasnu plućnu fazu. Period inkubacije je period od trenutka infekcije virusom do trenutka nastanka prvih simptoma. U ovom periodu replikacija virusa dostiže vrhunac. Obično traje oko 5 dana, ali može trajati od 2 do 14 dana. Simptomatska faza bolesti traje oko 7 dana i predstavlja period od nastanka prvih nespecifičnih simptoma do nastanka pneumonije. Rana plućna faza se karakteriše upalom pluća blažeg stepena i traje 3 do 5 dana, dok se kasna plućna faza, ukoliko nastane, karakteriše razvojem bilateralne pneumonije i ARDS-a. U ovoj fazi je imunski odgovor pacijenta najjači i dovodi do nastanka citokinske oluje.
Plućna faza se karakteriše imunološkim poremećajem, oštećenjem malih krvnih sudova pluća sa aktivacijom koagulacione kaskade i nastankom generalizovanog prokoagulantnog stanja. U kasnoj plućnoj fazi oštećenja pluća mogu da progrediraju do ireverzibilnih fibroproliferativnih promena, kada je potrebna primena produžene mehaničke ventilacije. Veoma često se klinički tok u najtežoj fazi komplikuje superinfekcijom i sepsom.

Poznavanje kliničkog toka bolesti je značajno zbog izbora adekvatnih dijagnostičkih postupaka i primene racionalne terapije. Tako će, npr. PCR test nazofaringealnog brisa imati najveću senzitivnost i specifičnost početkom simptomatske faze, dok će senzitivnost i specifičnost ovog testa opadati u ranoj i kasnoj plućnoj fazi. Serološki testovi neće pokazati prisustvo IgG i IgM antitela na SARS-CoV-2 virus $\mathrm{u}$ periodu inkubacije i u simptomatskoj fazi. Antivirusna terapija je efikasna samo $\mathrm{u}$ fazi virusne replikacije (simptomatska faza), dok je antiinflamatorna terapija efikasna tokom plućne faze bolesti. Primena kortikosteroidne terapije u plućnoj fazi ne dovodi do smanjenja produkcije antitela. Metilprednizolon ima bolji efekat $u$ poređenju sa deksametazonom zbog bolje penetracije u plućni parenhim (25). Terapiju rekonvalescentnom plazmom treba primeniti u početnim stadijumima bolesti jer se njome podstiče imunski odgovor pacijenta na COVID-19.

Dakle, terapija je krajnje dinamična i prati težinu kliničke slike i druge odlike pacijenata.

\section{I grupa pacijenata}

Ovu grupu sačinjavaju pacijenti bez značajnih komorbiditeta i sa blagom kliničkom slikom. To su pacijenti kojima nije potrebna kiseonična terapija ( $\mathrm{SpO}_{2}$ iznad $94 \%$ na sobnom vazduhu), sa stabilnim vitalnim parametrima (respiratorna frekvencija manja od $20 / \mathrm{min}$ ) i bez radioloških znakova pneumonije. Terapija je simptomatska: vitamin A kapi za nos 2 x 2 kapi, alfa-lipoinske kiseline tbl. 1 x 200 mg, alfakalcidol tbl. (Alpha D3) 1 x 2 mcg. Fizikalna terapija ovih pacijenata podrazumeva promene položaja pacijenta na svaka 2 sata (levi, desni bočni i potrbušni položaj - "prone”), kao i vežbe disanja spirobolom. Vitalni parametri sa posebnim osvrtom na $\mathrm{SpO}_{2}$ procenjuju se na svaka 2 sata, laboratorijske analize se uzimaju svakog 3. dana, a kod pogoršanja i ranije, dok se radiografsko snimanje pluća ponavlja na 5 . dan ili ranije u slučaju pogoršanja opšteg stanja pacijenta.

\section{II grupa pacijenata}

Ovu grupu čine pacijenti sa najmanjim oštećenjem pluća. Tu su pacijenti sa saturacijom manjom od $94 \%$ na sobnom vazduhu, respiratornom frekvencijom većom od 25/min i radiografskim znacima pneumonije, ali koji pozitivno reaguju na primenu kiseonične terapije $(4-10 \mathrm{l} / \mathrm{min}$, odnosno $\mathrm{FiO}_{2}$ - 0,28 do 0,4). Terapija obuhvata sve iz prethodne grupe, uz primenu polivitaminske i antivirusne terapije: Vitamin C ima značajnu ulogu u tretmanu ovih bolesnika zbog antiinflamatornog i antioksidativnog dejstva. Primenjuje se u dozi od $2 \mathrm{~g}$ do $6 \mathrm{~g}$ dnevno $\mathrm{u}$ intravenskoj infuziji ili per os. Ordiniraju se i cink 75 do $100 \mathrm{mg}$ p.o. jednom dnevno, melatonin do $10 \mathrm{mg}$ dnevno, uveče; 
favipiravir tbl. $1600 \mathrm{mg}$ p.o. prvi dan, zatim 2 x $600 \mathrm{mg}$ p.o. još 4 dana. Primena antivirusnih lekova se započinje u simptomatskoj fazi, tačnije u prvih 5 dana od nastanka simptoma jer je tada replikacija virusa na najvišem nivou. Antitrombocitna terapija (aspirin $300 \mathrm{mg}$ p.o. jednom dnevno) i antikoagulantna terapija (enoksapin $60 \mathrm{mg}$ jednom dnevno $s c$. ili $1 \mathrm{mg} / \mathrm{kg}$ na $12 \mathrm{~h}$ kod pacijenata sa visokim vrednostima D-dimera) imale su ključnu ulogu u sprečavanju nastanka mikrotromboze i koagulopatija. Kortikosteroidna terapija se primenjuje u plućnoj fazi bolesti i doziranje zavisi od težine kliničke slike. Metil prednizolon se daje u dozi od $40 \mathrm{mg} / 12 \mathrm{~h} i \mathrm{v}$. do $125 \mathrm{mg} / 12 \mathrm{~h}$ $i v$. kod teških oblika infekcije. Kiseonična potpora se obično izvodi kiseoničnom maskom, venturi maskom ili, u slučaju potrebe, primenom neinvazivne mehaničke ventilacije. Fizikalna terapija ovih pacijenata podrazumeva promene položaja pacijenta na svaka 2 sata (levi, desni bočni i potrbušni položaj - "prone") i vežbe disanja spirobolom. Saturacija se kod ovih pacijenata proverava svakog sata, laboratorijske analize se proveravaju svakog dana, dok se radiografsko snimanje pacijenata ponavlja svakog drugog dana. Kod ovih pacijenata je potrebno razmotriti dodatnu radiološku dijagnostiku u vidu CT grudnog koša.

III grupa pacijenata

U ovu grupu pacijenata spadaju pacijenti stariji od 60 godina ili pacijenti sa komorbiditetima, tačnije pacijenti koji su imali blago ili umereno oštećenje pluća, ali i povećan rizik da razviju teški oblik kliničke slike. Tu su takođe i gojazni pacijenti $(B M I \geq 30)$, dijabetičari $(H g b A 1 c \geq 8,0)$, hipertoničari, pacijenti sa hroničnim oboljenjem srca, pluća ili bubrega, kao i pacijenti koji su primali imunosupresivnu terapiju. Gojaznost je definitivno potvrđena kao loš prognostički faktor, verovatno zbog povećanog broja ACE2 receptora u masnom tkivu, koji imaju ključnu ulogu u patofiziologiji ove bolesti. Terapija kod ovih pacijenata je ista kao kod prethodne grupe, ali je monitoring obimniji i podrazumeva konstantno praćenje saturacije, EKG-a, neinvazivno merenje pritiska i, po potrebi, diureze. Ovim pacijentima je potrebno uraditi CT grudnog koša zbog procene zahvaćenosti plućnog parenhima.

U sledećim tabelama je prikazan protokol lečenja koji smo razvili u KBC „Dr D. Mišović-Dedinje“, a koji se zasniva na težini kliničke slike i odnosi se na pacijente koji nisu na mehaničkoj ventilaciji pluća. Protokol podrazumeva prilagođavanje terapijskog pristupa pogoršanju bolesti (slika 2A, 2B).

Kako se težina kliničke slike pogoršava, prilagođava se i terapija i obično se podiže invazivnost terapijskih postupaka. Najznačajnije je pratiti tok bolesti i rano prepoznati moguće pogoršanje, tj. proceniti fazu u kojoj se bolesnik nalazi. Kako je respiratorni sistem kod pacijenata kod kojih bolest progredira do najteže forme dominantno zahvaćen, tako se posebna pažnja posvećuje adekvatnoj proceni oksigenacije i gasne razmene.

$\mathrm{Za}$ inicijalnu procenu gasne razmene korisnim se pokazao tzv. modifikovani indeks oksigenacije $(\mathrm{MIO}=$ $\mathrm{SpO}_{2} / \mathrm{FiO}_{2}$ ). Vrednost $\mathrm{MIO}<315$ sugeriše ARDS, odnosno ukazuje na težinu bolesti, tj. zahvaćenost pluća.

Predmet ovog rada su teški pacijenti, sa potrebom za

\begin{tabular}{|c|c|c|c|}
\hline STEPEN BOLESTI & MEDIKAMENTI & $\mathrm{FIZ}$. TH. $+\mathrm{O} 2$ & Rtg, LAB. ANALIZE \\
\hline $\begin{array}{l}\text { Bolesnici bez komorbiditeta i } \\
\text { sa blagim oblikom infekcije } \\
\text { (hospitalizovani pacijenti sa } \\
\mathrm{SatO}_{2}>94 \% \text { na FiO } 20.21 \\
\mathrm{RR}<20 / \text { min; i bez radioloških } \\
\text { znakova pneumonije) ili } \downarrow L e+/-\end{array}$ & $\begin{array}{l}\text { Simptematska terapija izolacija } \\
\text { Th anosmije: vitamin A kapi za nos 2x2 kapi, alfa lipoinska kiselina tbl. 1×200mg, } \\
\text { alfakalcidol tbl. (Alpha D3) 1x2 mcg (MOŽE I NE MORA) }\end{array}$ & $\begin{array}{c}\text { Promena položaja u } \\
\text { krevetu na 2h (levi } \\
\text { desni bok, potrbušni } \\
\text { položai) } \\
+ \\
\text { Yežke Spirobollom }\end{array}$ & $\begin{array}{l}\text { Pratiti } \mathrm{SatO}_{2} \text { na } 2 \mathrm{~h} \\
\text { Rtg pulmo na } 5 \text { dana (ili } \\
\text { ranije u pegeršanju) } \\
\text { Lab.analize na } 3 \text { dana (ili } \\
\text { ranije u pegeršanju) }\end{array}$ \\
\hline 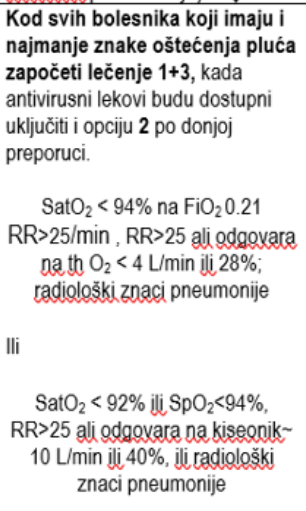 & 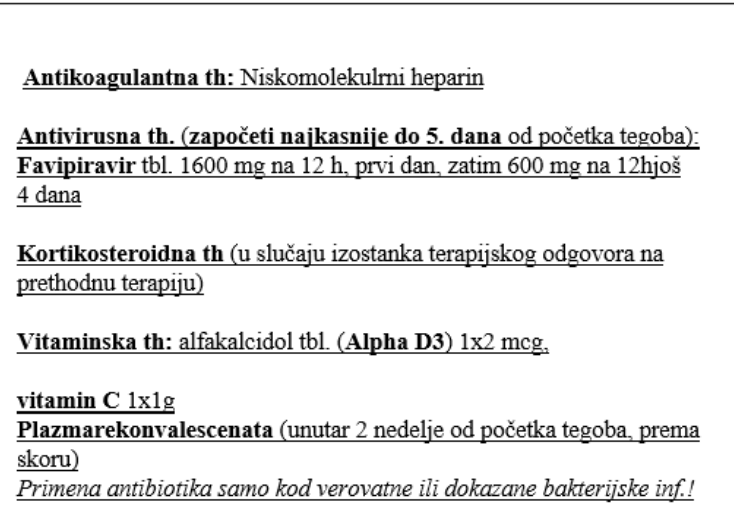 & $\begin{array}{c}\text { Promena peložaja u } \\
\text { krevetu na 2h (levi } \\
\text { desni bek, potrbušni } \\
\text { peložai) } \\
+ \\
\text { Yežbe Spirobollom } \\
+ \text { O2 Ventura maska } \\
\text { (boja konektorai } \\
\text { protok prema želienoj } \\
\text { inspiraternoi konc. } \mathrm{O}_{2} \text { ) } \\
\text { IIi NIV }\end{array}$ & $\begin{array}{l}\text { Pratiti } \mathrm{SatO}_{2} \text { na } 1 \mathrm{~h} \\
\text { Rtg pulmo na } 2 \text { dana (ili } \\
\text { ranije u pegoršanju) } \\
\text { Lab.analize svaki dana (ili } \\
\text { ranije u Regoršanju) } \\
\text { GASNE ANALIZE } \\
\text { Razmotriti CT Rluća }\end{array}$ \\
\hline 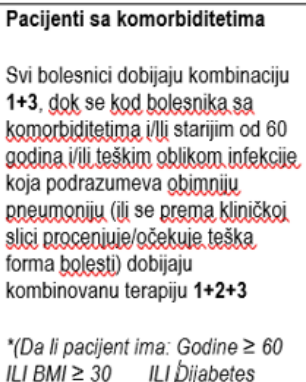 & $\begin{array}{l}\text { Antikoagulantna th: Niskomolekulrni heparin } \\
\text { Vitaminska th: alfakalcidol tbl. (Alpha D3) } 1 \times 2 \mathrm{mcg} \text {, vitamin C 1x1g } \\
\text { Oksigenoterapija: nazalni kateter ili maska (O2 10-15 L/min) } \\
\text { Antivirusnath. (akoje prošlo manje od 5. dana od početkategoba)Favipiravir } \\
\underline{\text { (kao gore) ili Remdesivir(200mg iv prvi dan pa } 100 \mathrm{mg} \text { iv narednih } 9 \text { dana) }} \\
\text { Kortikosteroidna th ili biološka terapija } \\
\text { Antibiotska th: prema vodiču za racionalnu primenu antibiotika, } \\
\text { Plazma rekonvalescenata (unutar2 nedelje od početka tegoba, premaskoru) }\end{array}$ & 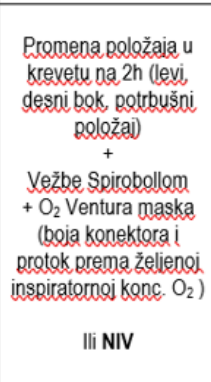 & $\begin{array}{l}\text { Pratiti } \mathrm{SatO}_{2} \text { na } 1 \mathrm{~h} \\
\text { Rtg pulme na } 2 \text { dana (ili } \\
\text { ranije u Regeršanju) } \\
\text { Lab.analize sxaki dana (ili } \\
\text { ranije u Regoršanju) } \\
\text { GASNE ANALIZE } \\
\text { Razmetriti CT pluća }\end{array}$ \\
\hline
\end{tabular}

Slika 2A. Protokol lečenja COVID-19 pacijenata u odnosu na težinu kliničke slike. 


\begin{tabular}{|c|c|c|c|}
\hline $\begin{array}{l}\text { (HgbA1c } \geq 8.0) \quad \text { ILI } \\
\text { Hronično oboljenje } \\
\text { srca/hipertenziju ILI Hronično } \\
\text { plućno oboljenje ILI } \\
\text { Imunosuprimiran }{ }^{*} \text { ) }\end{array}$ & 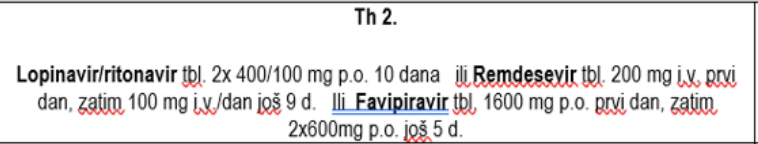 & & \\
\hline $\begin{array}{l}\text { Težak oblik infekcije } \\
\text { U belesnika sa teškim oblikom } \\
\text { infekcije koja zahteva lečenje u } \\
\text { JIL moguće je primeniti sve } \\
\text { dostupne mere intenzivnog } \\
\text { lečenja (kombinovano lečenje, } \\
\text { imunomodulatore i sl.). } \\
\\
\mathrm{SpO}_{2}<88 \% \text { ili } 94 \% \text {, RR>25 i pored } \\
60 \% \mathrm{protoka} \text { kiseanika - } 15 \mathrm{~L} / \mathrm{min} \\
\mathrm{SpO}_{2} / \mathrm{FiO}_{2}<315 \text { - ARDS } \\
\mathrm{PaO}_{2} / \mathrm{FiO}_{2}<300 \text { - ARDS }\end{array}$ & 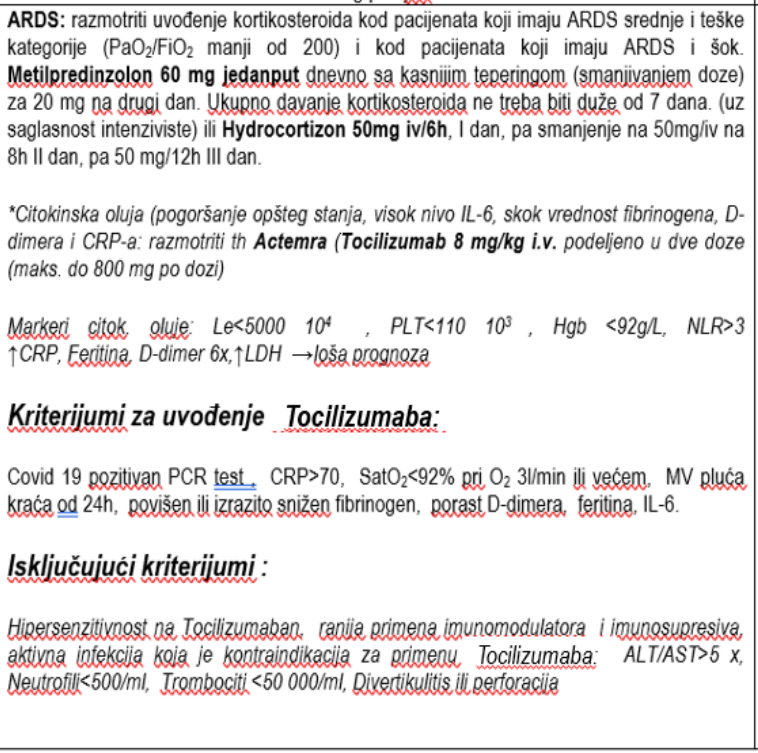 & 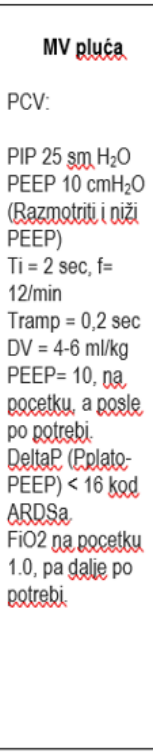 & 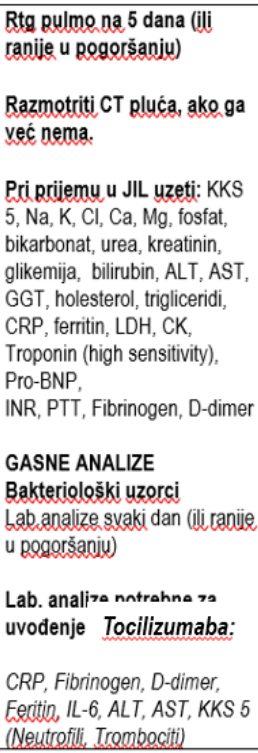 \\
\hline
\end{tabular}

\section{TRIJAŽA BOLESNIKA NA OSNOVU POTREBE ZA OKSIGENOTERAPIJOM}

\section{A) Zeleno: $: \mathrm{SpO}_{2}>88$ ili $94 \%$, RR<20 udaha/min; \\ B) Žuto: $\mathrm{SpO}_{2}<88$ ili $94 \%, \mathrm{RR}>25$ ali edgoxara na kiseonik $<4 \mathrm{~L} / \mathrm{min}$ ili $28 \%$; \\ C) Orange $\left(\mathrm{SpO}_{2}<94 \%, \mathrm{RR}>25\right.$ ali odgovara na kiseonik $10 \mathrm{~L} / \mathrm{min}$ ili $40 \%$ \\ D) Crurno $\left(\mathrm{SpO}_{2}<88 \%\right.$ ili $94 \%, \mathrm{RR}>25 \mathrm{i}$ pored $60 \% \sim 15 \mathrm{l} / \mathrm{min}$ protoka kiseonika. $\mathrm{SpO}_{2} / \mathrm{FiO}_{2}<315$ - ARDS}

Slika 2B. Protokol lečenja COVID-19 pacijenata u odnosu na težinu kliničke slike.

respiratornom potporom. Osnovni vid te potpore je kiseonična terapija (oksigenoterapija), koja se primenjuje na različite načine, u zavisnosti od procene gasne razmene pacijenta. Osnovni alati za tu procenu su pulsna oksimetrija i gasne analize arterijske krvi, uz kliničku sliku pacijenta.

Pulsna oksimetrija pruža podatke o saturaciji hemoglobina periferne krvi kiseonikom. Oksimetar se u vidu štipaljke postavlja na jagodicu prsta (ili ušnu resicu), a rezultat se očitava na monitoru grafički (u vidu krivulje) i numerički (u procentima) (slika 3). Normalne vrednosti $\mathrm{SpO}_{2}$ kod zdravih osoba su iznad 95\%, dok su kod bolesnika sa hroničnim plućnim bolestima niže.

Gasne analize arterijske krvi daju informacije o adekvatnosti alveolarne oksigenacije (parcijalni pritisak kiseoni$\mathrm{ka} \mathrm{u}$ arterijskoj krvi - $\mathrm{PaO}_{2}$ ), ventilacije (parcijalni pritisak ugljen-dioksida u arterijskoj krvi, $\mathrm{PaCO}_{2}$ ), kao i o acidobaznom statusu pacijenta. Iz gasnih analiza se dobijaju i druge korisne informacije, kao npr. vrednosti elektrolita, glikemije, laktata, hematokrit (tabela 1).

U nastavku je prikazan osnovni princip tumačenja gasnih analiza arterijske krvi, po koracima.

PRVI KORAK: Pogledaj pH i proceni da li je u pitanju acidoza ili alkaloza.

DRUGI KORAK: Pogledaj osnovne parametre:

a) $\mathrm{PaCO}_{2}$ (respiratorna komponenta acidobazne ravnoteže) - da li su vrednosti iznad ili ispod normalnih?

b) bikarbonate i BE/BD (bazni eksces/bazni deficit metaboličke komponente acidobazne ravnoteže) - da li su vrednosti ispod ili iznad normalnih?

TREĆI KORAK: Kako se te komponente slažu sa pH?

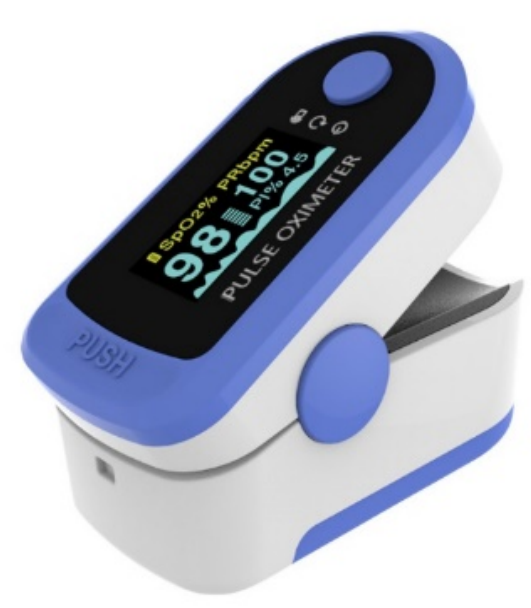

Slika 3. Pulsni oksimetar (portabilni).

Tabela 1. Vrednosti parametara gasnih analiza arterijske krvi u acidobaznoj ravnoteži i njenim poremećajima - acidozi i alkalozi.

\begin{tabular}{llll}
\hline Parametar & Normalno & Kretanje u acidozi & Kretanje u alkalozi \\
\hline $\mathrm{pH}$ & 7,40 & $<7,40$ & $>7,40$ \\
$\mathrm{PaCO}_{2}$ & $40 \mathrm{mmHg}$ & $>40 \mathrm{mmHg}$ & $<40 \mathrm{mmHg}$ \\
$\mathrm{PaO}_{2}$ & $100 \mathrm{mmHg}$ & & \\
$\mathrm{Bikarbonati}$ & $24 \mathrm{mEq} / \mathrm{L}$ & $<24 \mathrm{mEq} / \mathrm{L}$ & $>24 \mathrm{mEq} / \mathrm{L}$ \\
$\mathrm{BE} / \mathrm{BD}$ & $0 \mathrm{mEq} / \mathrm{L}$ & $<0 \mathrm{mEq} / \mathrm{L}$ & $>0 \mathrm{mEq} / \mathrm{L}$ \\
\hline
\end{tabular}

Legenda: $\mathrm{PaCO}_{2}$ - parcijalni pritisak $\mathrm{CO}_{2} \mathrm{u}$ arterijskoj krvi; $\mathrm{PaO}_{2}$ - parcijalni pritisak $\mathrm{O}_{2} \mathrm{u}$ arterijskoj krvi; $\mathrm{BE} / \mathrm{BD}$ - bazni eksces ili deficit. 
Ono što se slaže sa $\mathrm{pH}$ (respiratorna ili metabolička komponenta) je PRIMARNI POREMEĆAJ acidobazne ravnoteže.

Ako se druga komponenta kreće u suprotnom pravcu, to je SEKUNDARNI POREMEĆAJ acidobazne ravnoteže.

Ako se vrednosti obe komponente kreću u istom pravcu, onda je to KOMBINOVANI POREMEĆAJ (slika 4).

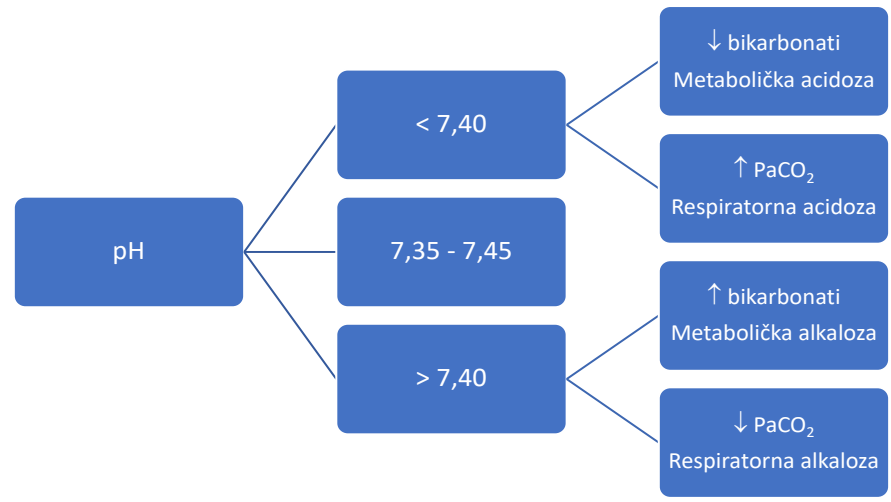

Slika 4. Odnos pH i komponenti acidobazne ravnoteže. Legenda: $\mathrm{PaCO} 2$ - parcijalni pritisak $\mathrm{CO} 2 \mathrm{u}$ arterijskoj krvi.

Procena oksigenacije

1. $\mathrm{PaO}_{2} / \mathrm{FiO}_{2}$. Najjednostavniji način za procenu oksigenacije iz gasnih analiza arterijske krvi jeste određivanje odnosa $\mathrm{PaO}_{2}$ i frakcije $\mathrm{O}_{2}$ koja se isporučuje pacijentu $\left(\mathrm{FiO}_{2}\right)$. Koristi se za određivanje težine akutnog plućnog oštećenja. $\mathrm{PaO}_{2} / \mathrm{FiO}_{2}$ bi trebalo da bude okvirno 500 (na sobnom vazduhu je $\mathrm{FiO}_{2}=0,21 ; \mathrm{PaO}_{2}$ normalno iznosi oko $100 \mathrm{mmHg} ; 100 / 0,21=476,2)$.

Ukoliko je $\mathrm{PaO}_{2} / \mathrm{FiO}_{2}$ :

$200-300=$ blago pogoršanje oksigenacije

$100-200=$ umereno pogoršanje oksigenacije

$<100=$ teško pogoršanje oksigenacije.

Procena oksigenacije se jednostavno može uraditi i kroz modifikovani indeks oksigenacije (MIO).

Primer: $\mathrm{SpO}_{2} 85 \%, \mathrm{FiO}_{2} 41 \%(0,41)$ : modifikovani indeks oksigenacije $=85: 0.41=\sim 207$, što ukazuje na ARDS. Ukoliko su vrednosti MIO nezadovoljavajuće, potvrdu loše gasne razmene dobijamo gasnom analizom arterijske krvi i određivanjem indeksa oksigenacije $\left(\mathrm{IO}=\mathrm{PaO}_{2} /\right.$ $\left.\mathrm{FiO}_{2}\right),(\mathrm{P} / \mathrm{F}$ odnos - odnos parcijalnog pritiska kiseonika u arterijskoj krvi i inspiratorne frakcije kiseonika).

Postoje brojni algoritmi postupaka u proceni i terapiji hipoksije. Jedan od njih je prikazan na slici 5 i 6 . Parametre oksigenacije treba uvek korelirati sa kliničkom slikom i odluku doneti na osnovu kliničke procene.

Nakon ovakve procene, odlučujemo se za određeni stepen respiratorne podrške, ali i za smeštaj bolesnika na odeljenje, u PIN (poluintenzivna nega) ili u JIL. Sa pogoršanjem kliničke slike i gasne razmene prelazi se na sledeći, obično invazivniji vid respiratorne podrške. Obično je sledeći vid, posle jednostavne oksigenoterapije sa nazalnom. kanilom ili maskom, priključenje HFNC (engl. High flow nasal canulla), zatim je sledeći nivo podrške NIV - neinvazivna ventilacija pluća sa mašinom za disanje i na kraju je to IMV - invazivna mehanička ventilacija.

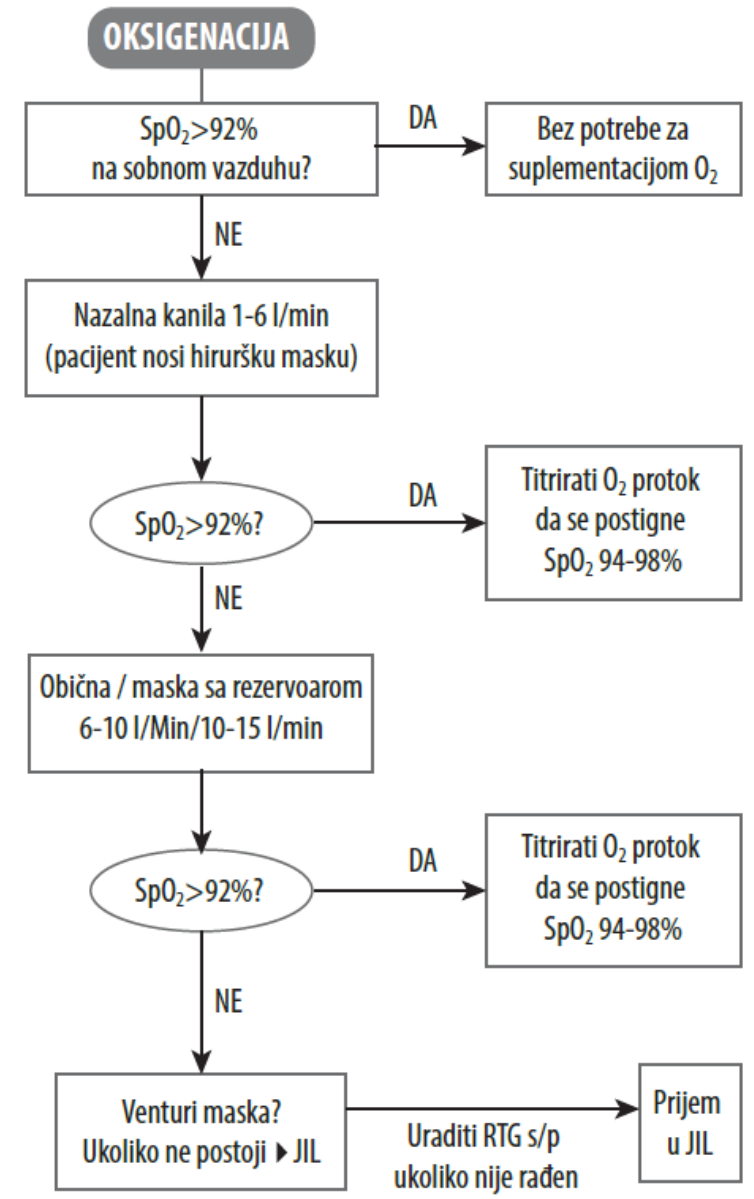

Slika 5. Procena i postupak konvencionalne kiseonične terapije usled hipoksije.

Redovno računati modifikovani indeks oksigenacije (MIO) $\mathrm{SpO}_{2} / \mathrm{FiO}_{2}$

$\mathrm{FiO}_{2}$ proceniti na osnovu protoka na sledeći način:

\begin{tabular}{|c|c|c|c|}
\hline \multicolumn{2}{|c|}{ Nazalna kanila } & \multicolumn{2}{|c|}{$\mathrm{O}_{2}$ Maska } \\
\hline $\begin{array}{c}\text { PROTOK } \\
\text { KISEONIKA }\end{array}$ & $\begin{array}{l}\text { PROCENJENI } \\
\mathrm{FlO}_{2}\end{array}$ & $\begin{array}{c}\text { PROTOK } \\
\text { KISEONIKA }\end{array}$ & $\begin{array}{c}\text { PROCENJENI } \\
\mathrm{FIO}_{2}\end{array}$ \\
\hline 11 & 0,25 & 61 & 0,35 \\
\hline 21 & 0,29 & $7 \mathrm{~L}$ & 0,41 \\
\hline 31 & 0,33 & $8 \mathrm{~L}$ & 0,47 \\
\hline $4 \mid$ & 0,37 & $9 \mathrm{~L}$ & 0,53 \\
\hline 51 & 0,41 & $10 \mathrm{~L}$ & 0,60 \\
\hline 61 & 0,45 & & \\
\hline \multicolumn{4}{|c|}{ Maska sa rezervoarom (protok 10-15L/min) } \\
\hline
\end{tabular}

PRIMER:

$\mathrm{SpO}_{2}=85 \% \mathrm{FiO}_{2}=0,41 \mathrm{MIO}=85 / 0,41=207$

MIO u ovom primeru ukazuje na ARDS.

Uraditi arterijske gasne analize i konsultovati dežurnog anestezioloiga.

Slika 6. Procena hipoksije na osnovu MIO indeksa. 
Indikacije za primenu neinvazivne i invazivne mehaničke ventilacije

Prelazak na HFNC za O terapiju ili NIV indikovan je ukoliko su prisutni jedan ili više parametara:

- pogoršanje respiratornog drajva (način disanja): dispneja, tahipneja $\geq 30 / \mathrm{min}$;

- $\mathrm{SaO}_{2}<92 \%$ i pored primenjene oksigenoterapije od $>51 /$ min ili putem nazalne kanile ili oronazalne maske (venturi maska);

- $\mathrm{PaO}_{2}<80 \mathrm{mmHg}$

- $200>\mathrm{P} / \mathrm{F}<250 \mathrm{mmHg}$.

Intubacija i primena invazivne mehaničke ventilacije je indikovana ukoliko su prisutni jedan ili više parametara:

- pogoršanje respiratornog drajva: dispneja, tahipneja $>35 / \mathrm{min}$;

- $\mathrm{SaO}_{2}<88 \%$ i pored primenjene HFNC ili NIV u trajanju od 2 sata;

- $\mathrm{PaO}_{2}<60 \mathrm{mmHg}$ i pored primenjene HFNC ili NIV u trajanju od 2 sata;

- $\mathrm{P} / \mathrm{F}<200 \mathrm{mmHg}$;

- $R O X$ indeks $=(\mathrm{SpO} 2 / \mathrm{FiO} 2) / \mathrm{FD}$ (količnik saturacije i $\mathrm{FiO} 2$ podeljen frekvencijom disanja/min). $R O X$ indeks ispod 5 uz D-dimer $>4000$ uz glomerulsku filtraciju (GFR) $<60 \mathrm{ml} / \mathrm{min}$ visoko su prediktivni za intubaciju.

I pored svih napora koji se čine na odeljenju, jedan broj pacijenata završi kao kritično oboleli u jedinici intenzivnog lečenja (JIL). Lečenje najtežih, kritično bolesnih pacijenata je specijalizovano lečenje pacijenata čija su stanja opasna po život i kojima su potrebni sveobuhvatna nega i stalno praćenje.

Ovi pacijenti se leče u JIL sa iskusnim i obučenim osobljem. Upravo nedostatak takvog osoblja i prostora uslovio je, u celom svetu, veliki mortalitet COVID-19.

Neke bolnice imaju posebne jedinice za posebne populacije (npr. kardiološke, traumatske, hirurške, neurološke, pedijatrijske ili neonatalne pacijente). Odeljenja intenzivnog lečenja zahtevaju i veliki broj i angažovanje medicinskih sestara jer je pacijentu neophodan visok intenzitet nege, uključujući lečenje i kontinuirano praćenje fizioloških parametara.

Ključne karakteristike kritično bolesnog pacijenta su teški respiratorni, kardiovaskularni ili neurološki, renalni ili drugi poremećaji, često u kombinaciji usled zahvaćenosti više organa ili organskih sistema. Treba naglasiti da je lečenje kritično bolesnih COVID-19 pacijenata školski primer definicije kritično bolesnih. COVID-19 u najtežem obliku napada sve organske sisteme i dovodi do iscrpljivanja fiziološke rezerve, što zahteva različite vidove podrške. Takvi pacijenti najpre ispoljavaju (u najvećem broju slučajeva) respiratornu insuficijenciju u obliku akutnog plućnog oštećenja (engl. Acute Lung Injury, ALI), odnosno akutnog respiratornog distres siundroma (ARDS), ali se na to veoma često i brzo nadovezuje superinfekcija, koja progredira do sepse, septičnog šoka i završava sa multisistemskom organskom insuficijencijom. Takvi pacijenti se klasifikuju u IV grupu.
IV grupa - kritično oboleli pacijenti

Ovu grupu čine kritično oboleli pacijenti, tačnije pacijenti sa teškim oblikom kliničke slike. U kliničkoj slici dominiraju glad za vazduhom - dispneja, tahipneja (respiratorna frekvencija preko 35/min), hipotenzija, tahikardija, često stanje početnog šoka. Saturacija je manja od $88 \%$ na sobnom vazduhu ili manja od $94 \%$ uprkos kiseoničnoj potpori od $151 / \mathrm{min}$, odnosno $\mathrm{FiO}_{2}$ od 0,6 , a kod razvijenog ARDS-a je $\mathrm{SpO}_{2} / \mathrm{FiO}_{2}<315$ ili $\mathrm{PaO}_{2} / \mathrm{FiO}_{2}<300$. Na osnovu pomenutih parametara, ovakvi pacijenti se smeštaju u JIL, gde je moguće primeniti sve dostupne mere intenzivnog lečenja. Oni zahtevaju kompletan i detaljan monitoring (EKG, neinvazivno i invazivno merenje krvnog pritiska, saturacija, temperatura, diureza). Laboratorijske analize se ponavljaju svakodnevno, a u slučaju potrebe i češće. Mikrobiološke analize se takođe uzimaju u pravilnim intervalima, a uvek u slučaju povišenja parametara zapaljenja (CRP, prokalcitonin) ili na osnovu kliničkih simptoma koji mogu ukazivati na bakterijsku ili gljivičnu superinfekciju. Ovim pacijentima se plasira arterijska kanila, radi kontinuiranog merenja krvnog pritiska i redovnije kontrole gasnih analiza, centralni venski kateter, zbog potrebe za višednevim primanjem terapije i primene parenteralne ishrane, kao i urinarni kateter radi preciznijeg merenja diureze i kontrole nadoknade tečnosti. U slučaju hemodinamske nestabilnosti ovih pacijenata koristi se invazivni hemodinamski monitoring u cilju hemodinamske optimizacije i ciljno usmerene nadoknade tečnosti, kao i primene adekvatnih vazopresora i inotro$\mathrm{pa}$, ali i adekvatne procene funkcije srčanog mišića. Zbog povećane količine citokina oslobođenih u krvotok, posledično se javljaju izrazita vazodilatacija i hipotenzija. Ovo stanje je dodatno potencirano nastankom sepse. Zato je u ovoj fazi često potrebna primena vazoaktivnih lekova, pre svega noradrenalina. Terapija obuhvata već navedenu terapiju, uz povećanje doze lekova. Primenjuje se pulsna doza metilprednizolona 250 do $500 \mathrm{mg} i v$. dnevno. Prestanak primene kortikosteroidne terapije mora biti postepen, do 2 nedelje nakon prestanka kiseonične podrške. Važno je napomenuti da antivirusni lekovi nemaju značajan efekat $\mathrm{u}$ ovoj fazi bolesti. Ukoliko dođe do nastanka superinfekcija, primenjuju se antibiotici širokog spektra dejstva, a nakon pristizanja rezultata antibiograma vrši se deeskalacija antibiotske terapije. Nadoknada tečnosti je od izuzetnog značaja. Cilj je održati euvolemiju sa delimično restriktivnom strategijom nadoknade tečnosti.

Jedan od tretmana koji se često koristi u JIL-u kod kritično obolelih pacijenata je okretanje pacijenata na trbuh ili "prone" pozicija. "Prone" pozicija se godinama koristi u terapiji ARDS-a zbog toga što je dokazano poboljšanje oksigenacije primenom ovog manevra. Mehanizam poboljšanja oksigenacije zasniva se na smanjenju gradijenta pleuranog pritiska od nezavisnih na zavisne delova pluća, povećavanje end-ekspiratornog volumena, poboljšavanje ventilaciono-perfuzionog odnosa, olakšavanje izbacivanja sekreta, što sve zajedno dovodi do poboljšanja plućne ventilacije (26). Ova pozicija je takođe protektivan mehanizam za nastanak VILI-ja (engl. ventilator induced lung injury) i 
povezana je sa smanjenim mortalitetom (27). Pacijenti se postavljaju u ovaj položaj 12 do 16 sati u kontinuitetu ili manje ukoliko dođe do hemodinamske ili kardiorespiratorne nestabilnosti. Pokazan je značajan benefit ovog manevra ukoliko se primeni u prvih 12 do $24 \mathrm{~h}$ od priključivanja pacijenta na mehaničku ventilaciju (28). Prilikom ovog manevra je ključno da tim koji okreće pacijenta bude uigran jer kod neiskusnih timova može doći do ozbiljnih povreda vratne kičme, povrede lica, dekubitusa i akcidentalne ekstubacije.

\section{Akutni respiratorni distres sindrom}

Akutni respiratorni distres sindrom je kompleksan sindrom koji može biti infektivne i neinfektivne etiologije (trauma, pankreatitis). Za dijagnozu ARDS-a se koristi tzv. Berlinska definicija, koja se sastoji od nekoliko kriterijuma (tabela 2) (29). Kod infekcije SARS-CoV-2 virusom osnovu ARDS-a čini ozbiljno hiperinflamatorno, citokinima posredovano oštećenje pluća. Citokinska oluja narušava normalan adaptivan odgovor na hipoksičnu vazokonstrikciju (30). Oštećenje alveolarnog epitela i endotela dovodi do povećane permeabilnosti i izlaska vode bogate proteinima, te posledično nastanka nekardiogenog edema pluća. $\mathrm{Na}$ to se nadovezuju nastanak atelektaza, smanjenje plućne komplijanse, poremećaj ventilaciono-perfuzionog odnosa i razvoj desno-levog šanta. Svi ovi faktori potenciraju nastanak hipoksemije. Istraživanja su pokazala da je komplijansa pluća ne-COVID pacijenata sa ARDS-om varijabilna, a kasnije se to potvrdilo i sa pacijentima obolelim od COVID-19. Ovo nam govori da se terapija koja se koristila u tretmanu ARDS ne-COVID pacijenata može primeniti i kod COVID-19 pacijenata (31). Nakon postavljanja dijagnoze ARDS-a cilj je otkriti i rešiti uzrok nastanka, kao i sprečiti oštećenja pluća neadekvatnom ventilacijom. Tipovi VILI-ja prikazani su u tabeli 3 (32).

Respiratorna podrška se primenjuje principom eskalacije. Počinje se neinvazivnim načinima kiseonične potpore.

Tabela 2. Berlinska definicija ARDS-a.

\begin{tabular}{|c|c|}
\hline Parametar & Definicija \\
\hline Vreme početka & $\begin{array}{l}\text { Unutar } 7 \text { dana od poznatog kliničkog uzroka ili } \\
\text { pogoršanja respiratornih simptoma }\end{array}$ \\
\hline $\begin{array}{l}\text { RTG ili CT } \\
\text { grudnog koša }\end{array}$ & $\begin{array}{l}\text { Bilateralna zasenčenja koja ne mogu da se objasne } \\
\text { torakalnim izlivima, kolapsom ili plućnim } \\
\text { nodusima }\end{array}$ \\
\hline $\begin{array}{l}\text { Poreklo } \\
\text { plućnog } \\
\text { edema }\end{array}$ & $\begin{array}{l}\text { Respiratorna insuficijencija koja se ne pripisuje } \\
\text { popuštanju srca ili višku tečnosti. Ukoliko nema } \\
\text { faktora rizika, potrebna je objektivna procena } \\
\text { (ehokardiografija) }\end{array}$ \\
\hline \multicolumn{2}{|l|}{ Hipoksemija } \\
\hline Blaga & $\begin{array}{l}200 \mathrm{mmHg}<\mathrm{PaO}_{2} / \mathrm{FiO}_{2}>300 \mathrm{mmHg} \text { sa PEEP- } \\
\text { om ili CPAP-om }>5 \mathrm{cmH}_{2} \mathrm{O}\end{array}$ \\
\hline Srednja & $\begin{array}{l}100 \mathrm{mmHg}<\mathrm{PaO}_{2} / \mathrm{FiO}_{2}>200 \mathrm{mmHg} \text { sa PEEP- } \\
\text { om }>5 \mathrm{cmH}_{2} \mathrm{O}\end{array}$ \\
\hline Teška & $100 \mathrm{mmHg}<\mathrm{PaO}_{2} / \mathrm{FiO}_{2}$ sa PEEP-om $>5 \mathrm{cmH}_{2} \mathrm{O}$ \\
\hline
\end{tabular}

Tabela 3. Tipovi VILI-ja.

\begin{tabular}{|c|c|}
\hline Povreda & Mehanizam \\
\hline Atelektrauma & $\begin{array}{l}\text { Ciklično otvaranje i zatvaranje } \\
\text { (kolabiranje) alveola }\end{array}$ \\
\hline Barotrauma & $\begin{array}{l}\text { Visoki transpulmonarni pritisak } \\
\text { oštećuje zidove alveola }\end{array}$ \\
\hline Biotrauma & $\begin{array}{l}\text { Oslobađanje citokina sa subseg- } \\
\text { mentnim plućnim i sistemskim } \\
\text { inflamatornim odgovorom }\end{array}$ \\
\hline Toksičnost kiseonika & $\begin{array}{l}\text { Nastanak slobodnih kiseoničnih } \\
\text { radikala }\end{array}$ \\
\hline $\begin{array}{l}\text { Samooštećenje pluća od strane } \\
\text { pacijenta } \\
\text { (engl. Patient self-inflicted lung } \\
\text { injury, P-SILI) }\end{array}$ & $\begin{array}{l}\text { Visok transpulmonarni pritisak } \\
\text { izazvan intenzivnom } \\
\text { inspiratornom snagom pacijenta }\end{array}$ \\
\hline Povreda smicanja (cepanja) & $\begin{array}{l}\text { Jake sile na spojevima kolabiranih } \\
\text { i otvorenih alveola }\end{array}$ \\
\hline Volutrauma & $\begin{array}{l}\text { Veliki disajni volumen dovodi do } \\
\text { prevelike distenzije alveola }\end{array}$ \\
\hline
\end{tabular}

(binazalni kateter, kiseonična maska, venturi maska, nazalna kanila sa visokim protokom, neinvazivna mehanička ventilacija) pa sve do intubacije i priključenja pacijenta na invazivnu mehaničku ventilaciju. U slučaju da nijedan vid respiratorne podrške ne daje željene rezultate, potrebno je razmotriti primenu ekstrakorporalne membranske oksigenacije.

Pacijentima kojima se saturacija otežano održava iznad 90\% ili kod kojih je primećen povećan disajni rad, primenjuje se HFNC, a zatim i neinvazivna ventilacija pozitivnim pritiskom (NIV). Neinvazivna ventilacija pozitivnim pritiskom obezbeđuje PEEP (pozitivni pritisak na kraju ekspirijuma u obliku kontinuiranog pozitivnog pritiska (engl. continuous positive airway pressure, CPAP). Ovaj oblik mehaničke ventilacije možemo primeniti preko „CPAP“ maske, "Full Face" maske ili helmeta. PEEP se podešava na $5-10 \mathrm{cmH}_{2} \mathrm{O}$ i postepeno povećava do $20 \mathrm{cmH}_{2} \mathrm{O}$, uz $\mathrm{FiO}_{2}$ od 0,4 do 1. Preporuka postavki NIV-a kod lečenja COVID-19 pacijenata je da se pokuša sa manjim $\mathrm{FiO}_{2}$, a većim PEEP-om, naravno sa ciljem pronalaska idealnog PEEP-a, tačnije, najbolje oksigenacije. Bilevel postavka NIV obezbeđuje dodatni i inspiratorni pritisak i može dovesti do nastanka VILI-ja, stoga treba biti izuzetno oprezan pri korišćenju ovog moda ventilacije (33). Procena respiratornog statusa pacijenata na HFNC i NIV vrši se nekoliko puta tokom dana. Pacijenti koji i pored svega ostanu tahidispnoični, uz povećan disajni rad i pored maksimalne podrške neinvazivnim načinima, priključivani su na invazivnu mehaničku ventilaciju. Donošenje odluke o intubaciji i priključivanju COVID-19 pacijenata na invazivnu mehaničku ventilaciju je pravi izazov. Dok su neki lekari zagovornici rane intubacije, drugi su zagovornici kasne (odložene) intubacije. Istina je verovatno na sredini, tj. rešenje je individualno za svakog pacijenta, na osnovu svih kliničkih parametara, opšteg stanja, CT skora, saturacije, gasnih analiza, broja respiracija i subjektivnog osećaja samog bolesnika. 
Redovno se procenjuju gasne analize iz arterijske krvi, gde se pored ostalih parametara $\left(\mathrm{pH}, \mathrm{pCO}_{2}, \mathrm{pO}_{2}, \mathrm{SO}_{2^{2}}\right.$ $\left.L a c, B E, \mathrm{HCO}^{3-}\right)$ poseban osvrt stavlja na $\mathrm{P} / \mathrm{F}$ indeks (Horowitz indeks) zbog njegove korelacije sa mortalitetom (tabela 4).

Tabela 4. Horowitz indeks i mortalitet kod ARDS-a.

\begin{tabular}{lll}
\hline Stepen ARDS-a & $\mathrm{PaO}_{2} / \mathrm{FiO} 2$ & Mortalitet \\
\hline Blagi & $200-300$ & $27 \%$ \\
Umeren & $100-200$ & $32 \%$ \\
Težak & $\leq 100$ & $45 \%$ \\
\hline
\end{tabular}

Intubacija i priključivanje na mehaničku ventilaciju COVID-19 pacijenata nosi veliki rizik zaražavanja medicinskog osoblja. Zbog toga je potrebno poštovati poseban protokol za intubaciju ovih pacijenata. Po ovom protokolu, koriste se svi dostupni intravenski anestetici (propofol, nesdonal, dormikum, hipnomidat, ketamin) veoma oprezno zbog hemodinamske nestabilnosti pacijenata. Kao relaksant se koristi rokuronijum i to u maksimalnoj dozi da bi se što brže stekli uslovi za bezbednu intubaciju. Da bi se povećala bezbednost medicinskog osoblja, prilikom intubacije se često koristi zaštita od pleksiglas providnih kutija i video-laringoskop. Nakon priključivanja na mehaničku ventilaciju pacijenti su kontinuirano sedirani, analgezirani i relaksirani. Dugodelujući i srednjedelujući relaksanti imaju veliku ulogu u mehaničkoj ventilaciji. Oni smanjuju asinhroniju između pacijenta i ventilatora, smanjuju disajni rad, poboljšavaju oksigenaciju, čak i smanjuju koncentraciju inflamatornih biomarkera $(34,35,36)$. Relaksaciju treba održavati kontinuirano do 48 časova, a zatim po potrebi bolusno, da bi se sprečila atrofija respiratorne muskulature. Imajući u vidu da primena relaksanata nije pokazala značajan uticaj na smanjenje mortaliteta kritično obolelih COVID-19 pacijenata, treba razmotriti njihovu manju upotrebu (37). Pacijente treba umereno sedirati uz redovne, svakodnevne prozore sedacije (povremeno ukidanje sedacije) radi procene stanja. Blaga sedacija povezana je sa boljim ishodom lečenja (38). Ipak, u uslovima velike asinhronije pacijenta i ventilatora, kada je povećan rizik za nastanak VILI-ja, neophodna je bila duboka sedacija. Što se tiče primene samih modova ventilacije, koriste se svi raspoloživi oblici: $V C V$ (volumenom kontrolisna ventilacija), $P C V$ (pritiskom kontrolisana ventilacija), PRVC (pritiskom vođena - volumenom kontrolisana ventilacija), $A P R V$ (inverzna ventilacija kontrolisana pritiskom sa neograničenim spontanim disanjem) SIMV (sinhronizovana mandatorna ventilacija), BiLevel (ventilacija sa dva nivoa pritiska), sa ciljem da pronađemo onaj koji će dovesti do najbolje oksigenacije pacijenta. Preporuke mehaničke ventilacije kod ARDS-a u COVID-19 zasnivaju se na primeni protektivne mehaničke ventilacije sa malim disajnim volumenom (4 - 8 $\mathrm{ml} / \mathrm{kg}$ ) i visokim PEEP-om (pozitivan pritisak na kraju ekspirijuma). Cilj mehaničke ventilacije u COVID-19 je održavanje adekvatne oksigenacije, uz sprečavanje nastanka VILI-ja. Osnovu ovakvog načina mehaničke ventilacije čine mali disajni volumen, adekvatan PEEP potreban da održi pluća rekrutovanim uz male pritiske u disajnim putevima (tabela 5) $(39,40)$. Pošto je ARDS heterogeni sindrom, potreban je indivudualan pristup jer se pacijenti međusobno značajno razlikuju. U suprotnom, primena uniformnog načina ventilacije kod svih COVID-19 pacijenata sa ARDS-om može dovesti do dodatnih značajnih oštećenja pluća. Određivanje idealnog PEEP-a za svakog pacijenta može biti ključan korak u ventilaciji ovih bolesnika jer je tanka granica između poboljšanja oksigenacije maksimalnim rekrutmentom alveola i nastanka VILI-ja (41). PEEP je koristan jer otvara i time omogućava ventilaciju kolabiranih alveola, poboljšava gasnu razmenu i smanjuje rizik od nastanka atelektotraume, dok, s druge strane, može biti i štetan zbog prekomernog širenja pluća, povećavajući plućnu vaskularnu rezistenciju, remeteći ventilaciono-perfuzione odnose i uzrokujući hemodinamsku nestabilnost smanjenjem "preloada" (tabela 5) (42). Iako još uvek nije definitivno dokazano, trenutne preporuke podržavaju primenu visokog PEEP-a kod bolesnika sa umerenim i teškim ARDS-om $\left(\mathrm{PaO}_{2} / \mathrm{FiO}_{2}<200 \mathrm{mmHg}\right)(43)$. Za primenu adekvatnog PEEP-a neophodna je dobra procena rekrutabilnosti pluća svakog pacijenta jer nizak PEEP kod dobro rekrutabilnih pluća neće pokazati značajan benefit, dok visok PEEP kod slabo rekrutabilnih pluća može dovesti do nastanka VILI-ja. Marini i Gattinoni sugerišu da postoje dva različita fenotipa ARDS-a kod COVID-19 pacijenata, H (engl. high - teška pluća) i L ((engl. low - laka, vazdušasta pluća) tipovi fenotipa, i da je potreban različit pristup u mehaničkoj ventilaciji. Razlika je bazirana na CT nalazu, komplijansi i rekrutabilnosti. Ipak, ovo još uvek nije definitivno dokazano i mehaničku ventilaciju treba sprovoditi prema gore navedenim preporukama (44).

Tabela 5. PEEP/ $\mathrm{FiO}_{2}$ - strategija titracije PEEP-a.

\begin{tabular}{lccccccc}
\hline $\mathrm{FiO}_{2}$ & 0,3 & 0,4 & 0,4 & 0,5 & 0,5 & 0,6 & 0,7 \\
$\mathrm{PEEP}$ & 5 & 5 & 8 & 8 & 10 & 10 & 10 \\
\hline & & & & & & & \\
& & & & & & & \\
\hline $\mathrm{FiO}_{2}$ & 0,7 & 0,7 & 0,8 & 0,9 & 0,9 & 0,9 & 1.0 \\
$\mathrm{PEEP}$ & 12 & 14 & 14 & 14 & 16 & 18 & $18-24$ \\
\hline
\end{tabular}

Tokom mehaničke ventilacije često je potrebno primenjivati rekrutment manevar. Tokom ovog manevra procenjuje se promena komplijanse pluća i šire zatvorene alveole kako bi se poboljšala gasna razmena. Rekrutment manevar je produžena inspiratorna pauza na visokom nivou CPAP, npr. $35-40 \mathrm{cmH}_{2} \mathrm{O}$ tokom 30 do 40 sekundi. Dokazano je da rekrutment manevar može značajno da poboljša oksigenaciju bez povišenog rizika od barotraume (45). Obavezno se procenjuje i "driving pressure", kroz razliku plato pritiska i PEEP-a. Ovaj pritisak reflektuje statičku komplijansu. Dokazano je da je "driving pressure" dobar pokazatelj mortaliteta kod ARDS-a, pri čemu visoki plato pritisak, samo uz visoki "driving pressure", povećava mortalitet kod pacijenata sa ARDS-om. S druge strane, PEEP deluje protektivno samo uz nizak "driving pressure" (46). 
Mehaničku ventilaciju treba sprovoditi tako da "driving pressure", uvek bude manji od $15 \mathrm{cmH}_{2} \mathrm{O}$. To se postiže smanjenjem disajnog volumena na 4 do $6 \mathrm{ml} / \mathrm{kg}$ i traženjem idealnog PEEP-a. Idealan PEEP je onaj pritisak koji dovodi do najmanjeg "driving pressure". Ovaj pritisak nam može značajno pomoći u identifikovanju pacijenata koji će imati benefit od visokog PEEP-a.

U slučaju potrebe za produženom mehaničkom ventilacijom potrebno je razmotriti potrebu za traheotomijom. U početku epidemije ova procedura je proskribovana usled mogućeg zaražavanja medicinskog osoblja. Ipak, u KBC „Dr Dragiša Mišović-Dedinje“ veoma smo brzo (već posle 2 nedelje od početka epidemije) doneli odluku i počeli da radimo traheotomije (prva traheotomija je kod nas urađena 9. aprila 2020.). Traheotomija smanjuje tzv. mrtav prostor, olakšava toaletu usne duplje i traheobronhijalnog stabla, omogućava znatno manju primenu lekova sa analgosedaciju, čime olakšava i skraćuje proces odvajanja pacijenta od mehaničke ventilacije, i u celini doprinosi skraćenju lečenja u jedinici intenzivnog lečenja. Ukupno smo uradili 89 traheotomija od 497 pacijenata lečenih na invazivnoj mehaničkoj ventilaciji, što je jedna od većih serija urađenih u svetu tokom pandemije.

Odvajanje COVID-19 pacijenata od mehaničke ventilacije je izuzetno težak zadatak. Proces odvajanja od mehaničke ventilacije započinje nakon početka rezolucije bolesti, koja se utvrđuje kliničkim i dijagnostičkim parametrima. Spremnost pacijenta na odvajanje od mehaničke ventilacije procenjuje se na osnovu objektivnih kriterijuma:

-zadovoljavajuće oksigenacije $\left(\mathrm{PaO}_{2} / \mathrm{FiO}_{2}>200 \mathrm{mmHg}\right.$ uz PEEP $\leq 5 \mathrm{cmH}_{2} \mathrm{O}$ ),

-hemodinamske stabilnosti, bez primene vazopresora,

- pacijent je budan ili se lako budi na poziv,

- pacijent može da kašlje i izbacuje sekret,

- indeksa brzog plitkog disanja (engl. Rapid shallow breathing index, RSBI) manjeg od 100 nakon dva minuta sprovođenja testa spontanog disanja; RSBI predstavlja odnos disajnog volumena i respiratorne frekvencije.

Ukoliko se utvrdi spremnost pacijenta na odvajanje od mehaničke ventilacije, sprovodi se test spontanog disanja tako što pacijenta prebacujemo na T-nastavak ili koristimo ventilatore koji u sebi imaju integrisan ovaj test kao mod ventilacije. Trajanje ovog testa je minimum 30 minuta. Tokom izvođenja ovog testa pacijent se pažljivo prati i procenjuje kroz vitalne funkcije i gasne analize. Parametri uspešnog testa spontanog disanja su:

- respiratorna frekvencija manja od 35/min,

- održavanje hemodinamske stabilnosti pacijenta (sistolni pritisak između 80 i $180 \mathrm{mmHg}$ ili promena sistolnog pritiska za manje od $20 \%$ u odnosu na početak testa),

- srčana frekvencija manja od 140/min,

- zadovoljavajuća oksigenacija $\left(\mathrm{SatO}_{2}>90 \%\right.$ ili $\mathrm{PaO}_{2}$ $>60 \mathrm{mmHg}$, uz $\mathrm{FiO}_{2}<0,4$ ),

- dobro tolerisanje ovog testa, nepokazivanje znakova povećanog disajnog rada.

Ukoliko su ovi parametri ispunjeni, pacijent se ekstubira i kiseonička potpora se nastavlja nekim od modova NIV-a ili HFNC.
Parametri neuspešnog testa spontanog disanja su pojačano znojenje, tahikardije, srčane aritmije, povećan disajni rad, hipotenzije, apneje, neadekvatne oksigenacije i ventilacije (povećanje $\mathrm{pCO} 2$ za više od $10 \mathrm{mmHg}$, smanjenje $\mathrm{pH}$ na manje od 7,32 ili smanjenje $\mathrm{pH}$ za više od 0,07 , $\mathrm{PaO}_{2}<60$ mmHg uz $\mathrm{FiO}_{2}>0,40, \mathrm{PaO}_{2} / \mathrm{FiO}_{2}<150$, pad saturacije za više od 5\%). Ukoliko se pojavi makar jedan od ovih parametara prekida se test spontanog disanja i nastavlja se sa mehaničkom ventilacijom.

Mikrobiološke analize se kod COVID-19 kritično bolesnih pacijenata rade na svaki treći dan, a po potrebi i češće. U uslovima bakterijske superinfekcije primenjuju se antibiotici širokog spektra delovanja, a zatim se terapija deeskalira na osnovu antibiograma. Pacijentima sa akutnom bubrežnom insuficijencijom u JIL-u izvodi se hemodijafiltracija, sa ili bez korišćenja citosorba, radi uklanjanja citokina iz cirkulacije i prevazilaženja citokinske oluje. Svakodnevno se procenjuju kalorijske potrebe pacijenata i na osnovu toga sprovodi enteralna ili parenteralna ishrana.

Primer medikamentne i infuzione terapije za pacijente na IMV u JIL dat je na slici 7A, B, C.

\section{Antivirusni lekovi}

Kao što smo već rekli, postoje 2 mehanizma delovanja ovih lekova. Prvi je sprečavanje virusa da u uđe u ćeliju domaćina, dok je drugi supresija nekog od koraka virusne replikacije. Imajući u vidu mehanizam delovanja ovih lekova, ključan je trenutak njihove primene. Najvažnije je primeniti ih u fazi bolesti kada je virusna replikacija na visokom nivou. Remdesivir je lek koji je pokazao efikasnost protiv infekcije Ebola i Marburg virusa (47), ali i protiv različitih RNK virusa (koronavirusa MERS i SARS-CoV) (48). On inhibira virusnu RNK polimerazu. Remdesivir je u dozi od $200 \mathrm{mg}$ iv/ dan, prvog dana, a zatim $100 \mathrm{mg} i v /$ dan narednih 9 dana pokazao kliničko poboljšanje u $68 \%$ pacijenata (49). U nešto većem istraživanju, Spinner je sa svojim kolegama pokazao bolju efikasnost primene ovog leka u trajanju od samo 5 dana u poređenju sa 10 -dnevnom primenom (50). Zbog intravenske primene ovog leka, on se ordinira hospitalizovanim pacijentima. Favipiravir deluje tako što inhibira funkciju RNK zavisne RNK polimeraze, enzima koji učestvuje u transkripciji i replikaciji virusnog genoma (51). Primenjuje se u dozi od $1600 \mathrm{mg}$ p.o. prvi dan, zatim 2 x $600 \mathrm{mg}$ p.o. još 4 dana. Hlorokin je lek koji se koristi u lečenju malarije, HIV-a i reumatoidnog artritisa. Ovaj lek ima širok spektar antivirusnog delovanja sprečavanjem ulaska virusa u ćeliju i sprečavanjem replikacije virusnog genoma (52). Lopinavir je inhibitor antiretrovirusne proteaze i koristi se u kombinaciji sa ritonavirom u terapiji HIV-a. Ova kombinacija je pokazala pozitivne rezultate u borbi protiv SARS virusa (53). Ipak, sve je više istraživanja koja pokazuju da kombinacija ova dva leka nema efikasnost u lečenju COVID-19 (54). Iako se i dalje vode polemike o upotrebi i koristi koja se može očekivati od ivermektina, taj lek iz ne tako jasnih razloga ne nalazi zvanično mesto u protokolima lečenja COVID-19. Smatra se da je sve više dokaza u prilog upotrebi ivermektina i ne treba ga tek tako jednostavno odbacivati (55). 
Stevanović P. Lečenje kritično obolelih COVID-19 pacijenata: praktične smernice. MedPodml 2021, 72(3):49-64

\begin{tabular}{|c|c|c|c|}
\hline MEDIKAMENTI & & & NAPOMENA \\
\hline \begin{tabular}{l}
\multicolumn{1}{c}{ Antibiotici } \\
(po savetu infektologa ili prema \\
bakteriološkom nalazu ili \\
deskalaciono)
\end{tabular} & $\begin{array}{l}\text { Npr: Hemomycin (azitromicin) } 500 \mathrm{mg} / 24 \mathrm{~h} \mathrm{u} 100 \mathrm{ml} \\
0.9 \% \mathrm{NaCl} \text { ili } 5 \% \text { glukoze } \\
\text { Način davanja: Infuzija u trajanju od } 2 \mathrm{~h}\end{array}$ & & \\
\hline Antipiretik & $\begin{array}{l}\text { Paracetamol } 1 \mathrm{gr} / 100 \mathrm{ml} / 6-8 \mathrm{~h} \\
\text { Način davanja: Infuzija u trajanu } 15 \mathrm{~min} \text {. }\end{array}$ & EmCools ploče za hlađenje & \\
\hline Inhibitori protonske pumpe & $\begin{array}{l}\text { Controloc } 40 \mathrm{mg} / 12 \text { ili } 24 \mathrm{~h} \\
\text { Način davanja: iv } \\
\text { Kod krvarenja iz GIT } 80 \mathrm{mg} \text { iv a dalje kont. infuzija } 8 \mathrm{mg} / \mathrm{h} \\
(80 \mathrm{mg} / 50 \mathrm{ml} \text { fiz rastv } \rightarrow 5 \mathrm{ml} / \mathrm{h} \text { do isteka } 72 \mathrm{~h})\end{array}$ & & \\
\hline $\begin{array}{c}\text { Niskomolekularni heparin } \\
\text { (doziranje prema telesnoj masi) }\end{array}$ & $\begin{array}{l}\text { Npr: Enoksaparin (Clexane) } \\
\text { Način davanja:SC } 0,4 \mathrm{ml} 1-2 \times / 24 \mathrm{~h}\end{array}$ & $\begin{array}{l}\text { Čarape za vene na obe noge } \\
\text { Ili } \\
\text { SCD (intermitentne kompresivne } \\
\text { manžetne na obe noge) }\end{array}$ & $\begin{array}{l}\text { Kod terapijskog doziranja kontrola } \\
\text { anti-Xa } 4 \text { h nakon date poslednje doze }\end{array}$ \\
\hline Duretik & $\begin{array}{l}\text { Furosemid 20mg } \\
\text { Način davanja: iv pp ili } \\
\text { Kont . infuzija: } 120 \mathrm{mg} / 50 \mathrm{ml} \text { fiz.rastvora }(2-5 \mathrm{ml} / \mathrm{h} \text { prema } \\
\text { diuretskom odgovoru) }\end{array}$ & $\begin{array}{c}\text { Kod } A B l: \\
\text { Posle prve doze na } 2 \mathrm{~h} \text { duplirati dozu do } \\
\text { ukupne doze od } 2400 \mathrm{mg} \text { ilisol } \\
\text { manitol100+80mg furosemida }\end{array}$ & \\
\hline Mukolitik & $\begin{array}{l}\text { Fluimucil (acetilcistein) } 300 \mathrm{mg} / 3 \mathrm{ml} \\
\text { Način davanja: } 1 \text { amp razblažiti sa } 3 \mathrm{ml} \text { fiz. rastvora ili } \\
5 \% \text { gluk. dati iv ili u infuziji } 1-2 \times / 24 \mathrm{~h} \text {. } 2 \mathrm{~h} \text { posle antibiotika. }\end{array}$ & $\begin{array}{l}\text { Ili umesto iv. } 3 \mathrm{ml} \text { nerazblaženog } \\
\text { rastvora dati endotrahealno preko } \\
\text { zatvorenog sistema za aspiraciju. } 1-2 \\
\text { x/24h } \quad 5-10 \text { dana. } \\
\end{array}$ & \\
\hline Inhibitor karboanhidraze & Acetazolamide tbl $250 \mathrm{mg} 2 \times 1$ tbl preko gastrične sonde & (izdrobiti) & \\
\hline Prokinetici & $\begin{array}{l}\text { Klometol (metoklopramid) } 10 \mathrm{mg} / 2 \mathrm{ml} \\
\text { Način davanja: IV duže od } 3 \mathrm{~min} .2-3 \mathrm{x} / 24 \mathrm{~h}\end{array}$ & $\begin{array}{l}\text { Kada se pacijent hrani preko gastrične } \\
\text { sonde }\end{array}$ & Max.30mg/24h, odnosno 0,5 mg/kg \\
\hline \multirow[t]{2}{*}{ INFUZIONA TERAPIJA } & & & Restrikcija tečnosti \\
\hline & $\begin{array}{l}\text { Npr: } \\
\text { Sol Hartmani } 500 \mathrm{ml} \text { ili Sol Ringer } 500 \mathrm{ml} \\
\text { Sol } 5 \text { ili } 10 \% \text { Glukoza } 500 \mathrm{ml} \\
\text { Sol } 8 \% \text { Hepasol } 500 \mathrm{ml} \text { ili } 10 \% \text { Aminoven } 500 \mathrm{ml} \text { ili } 15 \% \\
\text { Aminoven } 500 \mathrm{ml} \\
\text { Smof lipid } 20 \% 100 \mathrm{ml}+\text { Vitalipid N } \\
\end{array}$ & & $\begin{array}{c}\text { Ukupan unos tečnosti ukjjučujući i enteralni } \\
\text { unos ne bi trebalo da bude veći od } 2-2,5 \mathrm{~L} \\
+ \\
\text { Gubitke usled proliva ili povraćanja } \\
\text { Voditi računa o količini tečnosti koja se koristi } \\
\text { za rastvaranje lekova koji se daju u } \\
\text { kontinuranim infuzijama }\end{array}$ \\
\hline Insulin & $\begin{array}{l}\text { Novorapid IJ u rastvor glukoze prema glikemiji ili } \\
\text { Kont . infuzija: } 50 \mathrm{lJ} / 50 \mathrm{ml} \text { fiz.rastvora -brzina prema glikemiji }\end{array}$ & & $\begin{array}{l}\text { Kontrola glikemije na } 1-3 \mathrm{~h} \text { ako se daje } \\
\text { kontinuirano }\end{array}$ \\
\hline $7,4 \% \mathrm{KCL}$ & $\begin{array}{l}20 \mathrm{ml} 7,4 \% \mathrm{KCL} \text { u infuziji od } 500 \mathrm{ml} \text { na perifernu venu } \\
\text { Ili } 30-40 \mathrm{ml} 7,4 \% \mathrm{KCL} \text { u infuziji od } 500 \mathrm{ml} \text { na centralnu venu }\end{array}$ & $\begin{array}{c}\mathrm{KCL} \text { pulvis a } 1 \mathrm{gr} \\
\text { Preko gastrične sonde prema nivou } \mathrm{Ku} \\
\text { serumu }\end{array}$ & $\begin{array}{c}\text { Prema serumskom nivou K } \\
\text { Dnevne potrebe bez gubitaka su } 60 \mathrm{mmol} \\
(60 \mathrm{ml} 7,4 \% \mathrm{KCl})\end{array}$ \\
\hline $\begin{array}{c}\text { Vitamini } \\
\text { (hidrosolubilni-dnevne potrebe) }\end{array}$ & $\begin{array}{l}\text { Soluvit Nu infuziji rastvora glukoze 1amp/24h } \\
\text { + Cvit 2ampule }\end{array}$ & & \\
\hline Vitamini & $\begin{array}{l}\text { Vitalipid N (liposolubilni-dnevne potrebe) } \\
\text { Način davanja: u infuziji lipda 1amp/24h }\end{array}$ & & Sadrži ulje soje, fosfolipide jajeta \\
\hline
\end{tabular}

Slika 7A. Medikamentozna i infuziona terapija za pacijente na IMV u JIL.

\begin{tabular}{|c|c|c|c|}
\hline Preparat kalcijuma & \begin{tabular}{|l} 
Ca glukonat $10 \%$ amp a $10 \mathrm{ml}$ \\
Način davanja: $u$ infuziji $1-2 \mathrm{amp} / 24 \mathrm{~h}$
\end{tabular} & & \\
\hline Preparat magnezijuma & $\begin{array}{l}\mathrm{MgSO}_{4} 20 \% \\
\text { Način davanja: u infuziji } 5-10 \mathrm{ml} / 24 \mathrm{~h}\end{array}$ & & Ne mešati sa kalcjumom \\
\hline Preparat fosfata & $\begin{array}{l}\text { Glycophos (1 mMol fosfata/ml) } \\
\text { Način davanja: } 5-10 \mathrm{ml} / 24 \mathrm{~h} \text { (u infuziji glukoze ili } \\
\text { aminokiselina u trajanju od } 8 \mathrm{~h} \text { ) }\end{array}$ & & \\
\hline Preparat gvožđa & $\begin{array}{l}\text { Ferrovin amp } \\
1 \text { amp u } 100 \mathrm{ml} \mathrm{fiz.} \mathrm{rastvora} \mathrm{-infuzija} \mathrm{u} \mathrm{trajanju} \mathrm{od} 30 \mathrm{~min} \text {. } / 24 \mathrm{~h}\end{array}$ & & \\
\hline $\begin{array}{l}\text { ENTERALNA ISHRANA PREKO } \\
\text { GASTRIČNE SONDE }\end{array}$ & $\begin{array}{l}\text { Npr: kod renalne insuficijencije } \\
\text { Renilon } 7,5125 \mathrm{ml}(249 \mathrm{kcal}, 9,1 \mathrm{gr} \text { proteina) } \\
\text { Preko sonde: početi sa } 50 \mathrm{ml} / 4 \mathrm{~h}+50 \mathrm{ml} \text { vode } \\
\text { Postepeno povećavati do sedmog dan na } 100 \mathrm{ml} / 4 \mathrm{~h}+50 \mathrm{ml} \\
\text { vode + Probiotik } 1 \mathrm{x} / 24 \mathrm{~h} \\
\\
\text { Npr: kod dijabetičara } \\
\text { Diason ili Diben (103kcal } / 100 \mathrm{ml}, 4,3 \mathrm{gr} \text { proteina } / 100 \mathrm{ml}) \\
\text { Preko sonde: početi sa } 50 \mathrm{ml} / 4 \mathrm{~h}+50 \mathrm{ml} \text { vode } \\
\text { Postepeno povećavati do sedmog dan na } 100 \mathrm{ml} / 4 \mathrm{~h}+50 \mathrm{ml} \\
\text { vode+ Probiotik } 1 \mathrm{x} / 24 \mathrm{~h} \\
\text { Npr: kod insuficijencije jetre } \\
\text { Fresubin hepa (1.3 kcal/ml) } \\
\text { Preko sonde: početi sa } 50 \mathrm{ml} / 4 \mathrm{~h}+50 \mathrm{ml} \text { vode } \\
\text { Postepeno povećavati do sedmog dan na } 100 \mathrm{ml} / 4 \mathrm{~h}+50 \mathrm{ml} \\
\text { vode+ Probiotik } 1 \mathrm{x} / 24 \mathrm{~h} \\
\text { Npr: kod ostalih } \\
\text { Fresubin ili Nutrison ili Nutridrink }(1 \mathrm{kcal} / \mathrm{ml}) \text { ili Nutrison } \\
\text { energy (1.5 kcal/ml) } \\
\text { Preko sonde: početi sa } 50 \mathrm{ml} / 4 \mathrm{~h}+50 \mathrm{ml} \text { vode } \\
\text { Postepeno povećavati do sedmog dan na } 100 \mathrm{ml} / 4 \mathrm{~h}+50 \mathrm{ml} \\
\text { vode+ Probiotik } 1 \mathrm{x} / 24 \mathrm{~h}\end{array}$ & $\begin{array}{l}\text { EN ima prednost u odnosu na PN ali } \\
\text { se mogu i kombinovati u zavisnosti od } \\
\text { opšteg stanja pacijenta. }\end{array}$ & $\begin{array}{l}\text { - NG songa 10-12 Fr } \\
\text { - provera aspiracijom gastričog sadržaja ili } \\
\text { Rtg } \\
\text { - uzglavlje kreveta podignuto do } 30^{\circ}-45^{\circ} \\
\text { - EN započeti unutar } 24-36 \mathrm{~h} \text { od prijema u } \\
\text { JIL Ili } 12 \mathrm{~h} \text { posle intubacije. } \\
\text { - početi sa } 25 \% \text { kalorijskog cilja } \\
\text { - prvih } 72 \mathrm{~h}-15-20 \mathrm{kcal} / \mathrm{kg} \text { stvarne } \\
\text { telesne mase, (ABV) što je } 70-80 \% \\
\text { kalorijskih potreba } \\
\text { - proteina od } 1,2-2,0 \text { gr/kg ABV/dan. } \\
\text { - bolje kontinuirano hranjenje preko } \\
\text { gravitacionog sistema ili pumpe } \\
\text { - može i bolusno na } 3 \text {-4h } \\
\text { - formula bez vlakana a sa ribljim uljem } \\
\text { se bolje podnose } \\
\text { - EN treba prekinuti kod pacijenta sa } \\
\text { hemodinamskom nestabilnošcu koji zahteva } \\
\text { podršku vazopresorima } \\
\text { - EN se može nastaviti nakon što je pacijent } \\
\text { adekvatno reanimiran i i ili je bio na stabilnoj } \\
\text { dozi vazopresor sa održavanim MAP > } 65 \\
\text { mmHg. } \\
\text { - minmalna EN dozvoljena i u toku ECMO, } \\
\text { čak i kada je pacijent u pron poziciji }\end{array}$ \\
\hline PARENTERALAN ISHRANA & $\begin{array}{l}\text { Npr: Oliclinomel N-7 1000ml (ukupne kcal 1200, } \\
\text { neproteinske kcal 1040, 160gr šećera, 24mmol K) } \\
\text { Način davanja: u infuziji preko centralne vene } 45-50 \mathrm{~m} / \mathrm{h} \\
\quad \text { Ili } \\
\text { Npr:SmofKabiven peripheral } 1206 \mathrm{ml} \text { (ukupne kcal } 800 \text {, } \\
\text { neproteinske kcal } 700,85 \mathrm{gr} \text { šećera, } 23 \mathrm{mmol} \text { K) } \\
\text { Način davanja: u infuziji preko periferne vene } 50-60 \mathrm{~m} / \mathrm{h}\end{array}$ & $\begin{array}{l}\text { Za } 70 \mathrm{~kg} \rightarrow 15 \mathrm{kcalx} 70=1050 \mathrm{kcal} \\
\text { - U trosegmentnu kesu se dodaju svi } \\
\text { vitamin, elektroliti, minerali, insulin } \\
\text { prema glikemiji, ali se ne sme dodati } \\
\text { zaledno Ca i Mg } \\
\text { - ne sme se dodavati preparat gvožđa }\end{array}$ & $\begin{array}{l}\text { - preko CVK ili periferne vene } \\
\text { - što pre započeti kod pacijenta visokog rizika } \\
\text { kod kojih nije izvodjjivo rano plasiranje } \\
\text { gastrične sonde } \\
\text { početi sa } 25 \% \text { kalorijskog cilja } \\
\text { - prvih } 72 \mathrm{~h} \text {-15-20 kcal/ kg stvarne } \\
\text { telesne mase, (ABV) što je } 70-80 \% \\
\text { kalorijskih potreba } \\
\text { - proteina od 1,2-2,0 gr/kg ABV/dan. }\end{array}$ \\
\hline
\end{tabular}

Slika 7B. Medikamentozna i infuziona terapija za pacijente na IMV u JIL. 
- Antibiotska terapija nije opravdana kod bolesnika koji imaju oblike 1 i 2 bolesti. Preventivna primena antibiotika, kao i započinjanje terapije rezervnim antibioticima je u suprotnosti sa Nacionalnim vodičem racionalne primene antibiotika (izdanje Ministarstva zdravlja RS 2018) i svetskim preporukama.

- U slučaju kliničke sumnje ili dokazane bakterijske/gljivične superinfekcije u terapiji se daju i antibakterijski/antigljivični lekovi po principu racionalne primene.

- Kod oblika 3, 4 i 5 antibiotska terapija se primenjuje po Nacionalnom vodiču (vanbolnička pneumonija). U slučaju dokazane bolničke ili ventilatorne pneumonije antimikrobne lekove primeniti shodno Nacionalnom vodiču (strana 42)

- Primena fluorohinolona je ograničena upozorenjima na neželjene efekte i kontraindikovana je kod pojedinih rizičnih grupa (videti upozorenje proizvođača i ALIMS)

- Za vanbolničke bakterijske pneumonije (kod pacijenata novoprimljenih u COVID bolnicu odeljenja i poluintenzivne nege) jedan od sledećih antibiotika: amoksicilin ( $1 \mathrm{~g} 3$ x dnevno PO), doksiciklin (100 mg 2 x dnevno PO), Azitromicin ( $500 \mathrm{mg} 1$ dnevno 3 dana ili $500 \mathrm{mg}$ prvog dana, potom $250 \mathrm{mg}$ do petog dana PO), Klaritromicin ( $500 \mathrm{mg} 2 \times$ dnevno PO)

- U slučaju prisutnih komorbiditeta (hroničnih bolesti srca, pluća, jetre, bubrega, šećerne bolesti, alkoholizma, maligniteta, asplenije, imunosupresivnih stanja): Monoterapija respiratornim fluorohinolonima (Moksifloksacin $400 \mathrm{mg}$ jednom dnevno PO, Levofloksacin $750 \mathrm{mg}$ jednom dnevno PO) ili kombinacija jednog beta-laktama sa jednim makrolidima ili doksiciklinom: Amoksicillin - klavulanat $500 \mathrm{mg} / 125 \mathrm{mg} 3$ $x$ dnevno ili 875 mg/125 mg 2 x dnevno PO ili Cefuroksim 500 mg 2 x dnevno PO (za teže oblike 750 mg 3 x dnevno IV), Cefpodoksim 200 mg $2 \times 1$ dnevno PO ili Cefprozil $500 \mathrm{mg} 2 \times$ dnevno PO + makrolidi (azitromicin, klaritromicin) ili doksiciklin u preporučenim dozama, PO

- U jedinicama intezivne nege i lečenja: Kombinacija jednog beta-laktama sa jednim makrolidom ili respiratornim fluorohinolonom: Ceftriakson $2 \mathrm{~g}$ dnevno IV, Cefotaksim $2 \mathrm{~g} 3$ x dnevno IV, Amicilin-sulbaktam 1,5 do $3 \mathrm{~g} 4 \mathrm{x}$ dnevno IV + Azitromicin ili respiratorni hinoloni (Moksifloksacin, Levofloksacin) u već preporučenim dozama, preferencijalno IV

- $\mathbf{U}$ intrahospitalnim i vetilaciono - asociranim pneumonijama (nastalim $\mathbf{4 8}$ do $\mathbf{7 2 h}$ nakon prijema ili započete arteficijalne ventilacije): U uslovima gde kao izazivač dominira Acinetobacter: Monoterapija karbapenemom (Imipenem/cilastatin $500 \mathrm{mg}$ (imipenema) $4 \times$ dnevno IV, Meropenem $1 \mathrm{~g} 3$ x dnevno IV) ili Ampicilin - sulbaktam 1,5-3gr 4x dnevno

U uslovima gde kao izazivač dominira Pseudomonas spp: Anti pseudomonasni beta-laktam sa makrolidom ili respiratornim fluorohinolonom: Piperacilin-tazobaktam 4,5 g 3x dnevno IV, Cefepim $2 \mathrm{~g} 3$ x dnevno IV, Ceftazidim $2 \mathrm{~g} 3$ x dnevno IV, Imipenem/cilastatin 500 mg (imipenema) $4 \mathrm{x}$ dnevno IV, Meropenem $1 \mathrm{~g} 3$ x dnevno IV + Azitromicin ili respiratorni hinolon (Moksifloksacin, Levofloksacin) u već preporučenim dozama, preferencijalno IV + Opciono, aminoglikozid do 5 dana, u standardnim dozama

- Kod suspektne methicillin-rezistetne Staphylococcus aureus (MRSA) ili epidermidis (MRSE), kao i infekcije multi-rezistentnim Streptococcus pneumoniae (MRSP) dodaje se: Vankomicin $15 \mathrm{mg} / \mathrm{kg} 2$ ili 3 x dnevno IV, Teikoplanin $400 \mathrm{mg}$ jednom dnevno, Linezolid 600 $\mathrm{mg} 2 \mathrm{x}$ dnevno IV

- Terapija u slučajevima izolacije karbapenem-rezistetnog Acinetobacter spp: Kolistin bolus 9000000 ij (ako je bubrežna funkcija očuvana), a nakon 12 sati ordinirati 4500000 ij na 12 sati + dodati kolistin inhalatorno 2000000 ij 3x dnevno +/- Meropenem u standardnoj dozi (kliničko iskustvo iz više naših centara govori u prilog kombinacije kolistin+meropenem, kao i in vitro podaci, dok američki vodiči ovu kombinaciju ne preporučuju, a daju preporuke protiv kombinacije kolistina sa tigeciklinom ili rimfapicinom).

- U slučaju izostanka terapijskog odgovora i/ili muliti-rezistentnih agensa, dodatni značai bi moglo imati mikrobiološka dijagnostika iz BAL -a.

Slika 7C. Antibiotska terapija u COVID-19 infekciji (preuzeto iz nacionalnog protokola za lečenje kovida - verzija 12.)

\section{Kortikosteroidna terapija}

Kortikosteroidi, kao antiinflamatorni lekovi, smanjuju progresiju oštećenja pluća i mortalitet kod COVID-19 pacijenata. Primenjuju se u plućnoj fazi bolesti, dok njihova primena u simptomatskoj fazi bolesti može da pogorša klinički tok bolesti zbog supresije imunskog sistema i smanjenja klirensa virusa. Koristi se deksametazon $6 \mathrm{mg}$ p.o. ili iv. ili metilprednizolon 40 $\mathrm{mg} / 12 \mathrm{~h} i v$. do $125 \mathrm{mg} / 12 \mathrm{~h} i v$. kod teških oblika infekcije. $\mathrm{U}$ brojnim istraživanjima je pokazana smanjena smrtnost pacijenata kojima je ordinirana kortikosteroidna terapija u plućnoj fazi bolesti (56).

\section{Terapija rekonvalescentnom plazmom}

Terapija rekonvalescentnom plazmom predstavlja transfuziju plazme osoba koje su se izlečile od COVID-19. Ova plazma sadrži neutrališuća antitela (IgM i IgG) na SARS-CoV-2. Mehanizam delovanja se zasniva na povećanju snage imunskog sistema ili poboljšanju imunskog odgovora odmah nakon infekcije. Zato je ovu terapiju najbolje primeniti u početnim stadijumima bolesti $(57,58)$. Ova terapija se i ranije koristila u borbi protiv MERS, SARS i H1N1 virusa (57). Brojna istraživanja ukazuju na bezbednost i kliničku efikasnost terapije rekonvalescentnom plazmom, kao i na smanjenje mortaliteta nakon primene ove terapije (59).
Potrebno je ipak više istraživanja ili meta-analiza da bi se definitivno potvrdila efikasnost ove terapije u borbi protiv COVID-19.

\section{Tocilizumab}

Tocilizumab je imunosupresivni lek, prevashodno korišćen u lečenju reumatoidnog artritisa. Predstavlja humanizovano monoklonsko antitelo protiv IL-6. Primenjuje se $8 \mathrm{mg} / \mathrm{kg}$ u dve podeljene doze u sporoj intravenskoj infuziji. Maksimalna pojedinačna doza iznosi $800 \mathrm{mg}$. Kriterijumi za primenu tocilizumaba su: pozitivan PCR test na SARS-CoV-2, CRP $>70, \mathrm{SpO}_{2}<92 \%$ pri $\mathrm{O}_{2} 3 \mathrm{l} / \mathrm{min}$ ili većem, MV pluća kraća od $24 \mathrm{~h}$, povišen ili izrazito snižen fibrinogen, porast D-dimera, feritina, IL-6 više od $5 \mathrm{x}$ od referentnih vrednosti. Tocilizumab se ne primenjuje kod pacijenata alergičnih na ovaj lek, prethodne primene imunomodulatora i imunosupresiva, prisustva aktivne infekcije, ALT/AST $>5 \mathrm{x}$, neutrofila $<500 / \mathrm{ml}$ i trombocita $<$ $50000 / \mathrm{ml}$.

\section{Baricitinib}

Baricitinib je selektivni i reverzibilni inhibitor Janus kinaze (JAK1 i JAK2) indikovan za lečenje reumatoidnog artritisa. U nekim studijama je pokazao smanjenje trajanja invazivne mehaničke ventilacije i vremena provedenog $\mathrm{u}$ JIL. Za konačne efekte ovog leka treba sakupiti još relevantnih dokaza. 


\section{Prevencija}

Bilo koja zdrava osoba koja je došla u kontakt sa zaraženom osobom ili sa predmetima kontaminiranim od strane zaražene osobe kijanjem ili kašljanjem ima rizik da se zarazi ovim virusom. Ukoliko zaražene osobe nisu izolovane, tj. u karantinu, postoji velika opasnost da dođe do zaražavanja cele zajednice. Da bi se ovo sprečilo postoje određene mere prevencije, kao što su održavanje socijalne i fizičke distance, sprečavanje okupljanja većeg broja ljudi, sprečavanje putovanja, izolacija zaraženih osoba, korišćenje zaštitnih maski, redovna higijena ruku, primena skrining testova, pravilan način kašljanja, izbegavanje dodirivanja nosa, usta i očiju, kao i adekvatna ventilacija prostorija. Pored svih terapijskih modaliteta i razvoja vakcina, poštovanje navedenih mera prevencije i dalje predstavlja najefikasniji način zaštite od ove bolesti (60). Podizanje javne svesti o prevenciji je takođe jedan od ključnih koraka u sprečavanju širenja COVID-19. U ovome možda i najveću ulogu imaju mediji, pomoću kojih se širokoj populaciji pružaju informacije o ovoj bolesti.

\section{Zaključak}

Novonastala virusna bolest COVID-19 izazvana SARS-Cov-2 virusom je stvorila ne samo ozbiljnu paniku među ljudima nego je i stavila na veliki ispit socijalnu kulturu i zdravstvenu infrastrukturu u celom svetu. Kao nikada do sada u istoriji čovečanstva, do izražaja su došle negativne strane društvenih medija, kao i brzina širenja informacija. Pored potrebe da se brzo i efikasno učine dostupnim značajne informacije vezane za COVID-19, javlja se more neproverenih, pa čak i lažnih informacija, koje često prave veliku zabunu i štetu. To je posebna dimenzija ove pandemije o kojoj se tek mora razgovarati da bi se doneli adekvatni zaključci za budućnost. Dostupnost brojnih informacija je uzrokovala lažni utisak da svako može lečiti ovu bolest, pa makar i ne bio zdravstvene struke. To jednostavno nije tačno. Lečenje COVID-19 treba prepustiti profesionalcima, a lečenje najtežih oblika bolesti - kritično obolelih COVID-19 pacijenata, ostaje veliki izazov.

Pandemija je ukazala na posebno mesto intenzivne medicine u zdravstvenom sistemu i ono se mora redefinisati u budućnosti. Neophodno je školovati više kadrova (kako lekara, tako i medicinskih tehničara) koji mogu da rade sa kritično obolelim pacijentima, a potrebno je i redefinisati standarde postelja intenzivne medicine u planu mreža zdravstvenih ustanova.

Identifikacija asimptomatskih bolesnika ostaje glavni problem u sprečavanju širenja COVID-19. Iako postoje lekovi koji su pokazali pozitivne rezultate u lečenju ove bolesti, još uvek ne postoji jedinstven lek koji će biti efikasan kod svih obolelih pacijenata. Rana dijagnostika, testiranje asimptomatskih i simptomatskih pacijenata i njihovih kontakata, izolacija i rana suportivna terapija ostaju ključni u prevenciji širenja i kontroli ove bolesti.
Ovaj rad je zasnovan na rezultatima rada brojnih medicinskih stručnjaka raznih specijalnosti širom sveta, tokom sada već višegodišnje pandemije COVID-19, ali i na našim iskustvima stečenim tokom lečenja naših bolesnika. Lekari i medicinski tehničari, nemedicinsko osoblje, kao $i$ $z$ dravstveni radnici iz drugih centara koji su nam pritekli $u$ pomoć u najtežim danima borbe sa COVID-19 tokom epidemije u Srbiji 2020-21-dali su svoj maksimum, i niko se nije povukao. Iskreno sam ponosan na sve što smo učinili tokom tog perioda.

\section{Literatura}

1. Abate1 MS, Checkol AY, Mantedafro B, Basu B. Prevalence and risk factors of mortality among hospitalized patients with COVID-19: A systematic review and Meta-analysis. Bulletin of the World Health Organization. E-pub: 24. April 2020.

2. Lu CW, Liu XF, Jia ZF. 2019-nCoV transmission through the ocular surface must not be ig-nored. Lancet. 2020; 395(10224):e39.

3. Petrosillo N, Viceconte G, Ergonul O, Ippolito G, Petersen E. COVID-19, SARS and MERS: are they closely related? Clin Microbiol Infect. 2020; 26(6):729-34.

4. Khan I, Ahmed Z, Sarwar A, Jamil A, Anwer F. The potential vaccine component for COVID-19: a comprehensive review of global vaccine development efforts. Cureus. 2020; 12(6):e8871.

5. Wu A, Peng Y, Huang B, Ding X, Wang X, Niu P, et al. Genome composition and divergence of the novel coronavirus (2019-nCoV) originating in China. Cell host \& microbe. 2020 Mar; 27(3):325-8.

6. Luan J, Lu Y, Jin X, Zhang L. Spike protein recognition of mammalian ACE2 predicts the host range and an optimized ACE2 for SARS-CoV-2 infection. Biochem Biophys Res Com-mun. 2020; 526(1):165-9.

7. BioRender. Coronavirus replication cycle (template). GoldmanIsraelow B. 2020. Available from: https://app.biorender.com/biorendertemplates/figures/5e99f5395fd61e0028682c01/t-5e56d97dlb689000850f8f93-coronavirus-replication-cycle.

8. Mason RJ. Pathogenesis of COVID-19 from a cell biology perspective. Eur Respir J. 2020; 55(4):2000607.

9. Gupta N, Zhao YY, Evans C.E. The stimulation of thrombosis by hypoxia. Thromb Res. 2019; 181:77-83.

10. Teuwen LA, Geldhof V, Pasut A, Carmeliet P. Author correction: COVID-19: the vasculature unleashed. Nat Rev Immunol. 2020; 20:1.

11. Zaim S, Chong JH, Sankaranarayanan V, Harky A. COVID-19 and multiorgan response. Curr Probl Cardiol. 2020; 45(8):100618.

12. Leisman DE, Deutschman CS, Legrand M. Facing COVID-19 in the ICU: vascular dysfunc-tion, thrombosis, and dysregulated inflammation. Intensive Care Med. 2020; 46:1-4.

13. Ackermann M, Verleden S, Kuehnel M, Haverich A, Welte T, Laenger F. Pulmonary vascular endothelialitis, thrombosis, and angiogenesis in Covid-19. N Engl J Med. 2020; 383:120-8.

14. Yang Y, Shen C, Li J, Yuan J, Yang M, Wang F, et al. Exuberant elevation of IP-10, MCP-3 and IL-1ra during SARS-CoV-2 infection is associated with disease severity and fatal out-come. medRxiv. 2020;

15. Diao B, Wang C, Tan Y, Chen X, Liu Y, Ning L, et al. Reduction and functional exhaustion of $\mathrm{T}$ cells in patients with coronavirus disease 2019 (COVID-19). Frontiers in immunology. 2020; 11:827.

16. Connors JM, Levy JH. COVID-19 and its implications for thrombosis and anticoagula-tion. Blood. 2020; 135(23):2033-40.

17. Lu X, Zhang L, Du H, Zhang J, Li YY, Qu J, et al. SARS-CoV-2 infection in children. N Engl J Med. 2020;382:1663-5.

18. Du Y, Tu L, Zhu P, Mu M, Wang R, Yang P, et al. Clinical Features of 85 Fatal Cases of COVID囚19 from Wuhan. A Retrospective Observational Study. Am J Respir Crit Care Med. 2020; 201(11):1372区9.

19. Xia J, Tong J, Liu M, Shen Y, Guo D. Evaluation of coronavirus in tears and conjunctival se-cretions of patients with SARS-CoV-2 infection. J Med Virol. 2020; 92(6):589-4. 
20. Vashist SK. In vitro diagnostic assays for COVID-19: recent advances and emerging trends. Diagnostics (Basel). 2020; 10(4): E202.

21. Tan W, Lu Y, Zhang J, Wang J, Dan Y, Tan Z, et al. Viral kinetics and antibody responses in patients with COVID-19. MedRxiv. 2020;

22. Ai T, Yang Z, Hou H, Zhan C, Chen C, Lv W, et al. Correlation of chest CT and RT-PCR test-ing in coronavirus disease 2019 (COVID-19) in China: a report of 1014 cases. Radiology. 2020; 296(2):E32-40.

23. Kanne J.P, Little B.P, Chung J.H, Elicker B.M, Ketai L.H. Essentials for radiologists on COVID-19: an update-radiology scientific expert panel. Radiology. 2020; 296(2):E113-4.

24. Wong HYF, Lam HYS, Fong AH, Leung ST, Chin TW, Lo CSY. Frequency and distribution of chest radiographic findings in COVID-19 positive patients. Radiology. 2020; 296(2):72-8.

25. Fadel R, Morrison AR, Vahia A, Smith ZR, Chaudhry Z, Bhargava P, Miller J, Kenney RM, Alangaden G, Ramesh MS. Early short-course corticosteroids in hospitalized patients with COVID-19. Clinical Infectious Diseases. 2020 Oct 15;71(16):2114-20.

26. Gattinoni L, Tognoni G, Pesenti A, Taccone P, Mascheroni D, Labarta V. Effect of prone posi-tioning on the survival of patients with acute respiratory failure. N Engl J Med. 2001; 345:568-73.

27. Mentzelopoulos S.D. Prone position reduces lung stress and strain in severe acute respiratory distress syndrome. Eur Respir J. 2005; 25:534-44.

28. Guérin C, Reignier J, Richard JC, Beuret P, Gacouin A, Boulain T. Prone positioning in severe acute respiratory distress syndrome. $\mathrm{N}$ Engl J Med. 2013; 368:2159-68.

29. Ranieri VM, Rubenfeld GD, Thompson BT, Ferguson ND, Caldwell E. ARDS Definition Task Force: Acute respiratory distress syndrome: the Berlin Definition. JAMA. 2012; 307:2526-33.

30. Fox SE, Akmatbekov A, Harbert JL, Li G, Brown JQ, Vander Heide RS. Pulmonary and car-diac pathology in Covid-19: the first autopsy series from New Orleans. The Lancet Resp. Med. 2020; 8(7):681-6.

31. Ziehr DR, Alladina J, Petri CR, Maley JH, Moskowitz A, Medoff $\mathrm{BD}$, et al. Respiratory path-ophysiology of mechanically ventilated patients with COVID-19: a cohort study. American journal of respiratory and critical care medicine. 2020; 201(12):1560-4.

32. Slutsky A.S, Ranieri V.M. Ventilator-induced lung injury. N Engl I Med. 2013; 369:2126-36.

33. Frat J.P, Thille A.W, Mercat A, Girault C, Ragot S, Perbet S. Highflow oxygen through nasal cannula in acute hypoxemic respiratory failure. N Engl J Med. 2015; 372:2185-96.

34. Alhazzani W, Alshahrani M, Jaeschke R, Forel J, Papazian L, Sevransky J. Neuromuscular blocking agents in acute respiratory distress syndrome: a systematic review and meta-analysis of randomized controlled trials. Crit Care. 2013; 17(2):1-0.

35. Gainnier M, Roch A, Forel J.M, Thirion X, Arnal J.M, Donati S. Effect of neuromuscular blocking agents on gas exchange in patients presenting with acute respiratory distress syn-drome. Crit Care Med. 2004; 32:113-9.

36. Forel JM, Roch A, Marin V, Michelet P, Demory D, Blache JL. Neuromuscular blocking agents decrease inflammatory response in patients presenting with acute respiratory distress syndrome. Crit. Care Med. 2006; 34:2749-57.

37. The National Heart, Lung, and Blood Institute. PETAL Clinical Trials Network: Early neuro-muscular blockade in the acute respiratory distress syndrome. N Engl J Med. 2019; 380:1997-2008.

38. Fuller BM, Roberts BW, Mohr NM, Knight WA, Adeoye O, Pappal RD. The ED-SED Study: a multicenter, prospective cohort study of practice patterns and clinical outcomes associated with emergency department sedation for mechanically ventilated patients. Crit Care Med. 2019; 47:1539-48.

39. Griffiths MJD, McAuley DF, Perkins GD, Barrett N, Blackwood B, Boyle A. Guidelines on the management of acute respiratory distress syndrome. BMJ Open Respir Res. 2019; 6:e000420.

40. Fan E, Del Sorbo L, Goligher EC, Hodgson CL, Munshi L, Walkey AJ. An Official American Thoracic Society/European Society of Intensive Care Medicine/Society of Critical Care Medi-cine Clinical Practice Guideline: mechanical ventilation in adult patients with acute respiratory distress syndrome. Am J Respir Crit Care Med. 2017; 195:1253-63.
41. Del Sorbo L, Tonetti T, Ranieri VM. Alveolar recruitment in acute respiratory distress syn-drome: should we open the lung (no matter what) or may accept (part of) the lung closed? Intensive Care Med. 2019; 45:1436-9.

42. Brower RG, Matthay MA, Morris A, Schoenfeld D, Thompson BT. Acute Respiratory Dis-tress Syndrome Network, Ventilation with lower tidal volumes as compared with traditional tidal volumes for acute lung injury and the acute respiratory distress syndrome. $\mathrm{N}$ Engl J Med. 2000; 342:1301-8.

43. Poston JT, Patel BK, Davis AM. Management of critically ill adults with COVID-19. JAMA. 2020; 323(18):1839-41.

44. Marini JJ, Gattinoni L. Management of COVID-19 respiratory distress. JAMA. 2020; 323(22):2329-30.

45. Goligher EC, Hodgson CL, Adhikari NKJ, Meade MO, Wunsch $\mathrm{H}$, Uleryk E. Lung recruit-ment maneuvers for adult patients with acute respiratory distress syndrome. A systematic re-view and meta-analysis. Ann Am Thorac Soc. 2017; 14:S304-11.

46. Amato MBP, Meade MO, Slutsky AS, Brochard L, Costa ELV, Schoenfeld DA. Driving pressure and survival in the acute respiratory distress syndrome. N Engl J Med. 2015; 372:747-55.

47. Warren TK, Jordan R, Lo MK, Ray AS, Mackman RL, Soloveva V, et al. Therapeutic efficacy of the small molecule GS-5734 against Ebola virus in rhesus monkeys. Nature. 2016; 531(7594):381-5.

48. Agostini ML, Andres EL, Sims AC, Graham RL, Sheahan TP, Lu X, et al. Coronavirus sus-ceptibility to the antiviral remdesivir (GS5734 ) is mediated by the viral polymerase and the proofreading exoribonuclease. mBio. 2018; 9(2):e00221-18.

49. Grein J, Ohmagari N, Shin D, Diaz G, Asperges E, Castagna A, et al. Compassionate use of remdesivir for patients with severe COVID-19. N Engl J Med. 2020; 382(24):2327-36.

50. Spinner CD, Gottlieb RL, Criner GJ, Arribas Lopez JR, Cattelan AM, Soriano Viladomiu A, et al. Effect of remdesivir vs standard care on clinical status at 11 days in patients with mod-erate COVID-19: a randomized clinical trial. JAMA. 2020; 324(11):1048-57.

51. Shu B, Gong P. Structural basis of viral RNA-dependent RNA polymerase catalysis and trans-location. Proc Natl Acad Sci USA. 2016; 113(28):E4005-14.

52. Devaux CA, Rolain JM, Colson P, Raoult D. New insights on the antiviral effects of chloro-quine against coronavirus: what to expect for COVID-19? Int J Antimicrob Agents. 2020; 55(5):105938.

53. Vastag B. Old drugs for a new bug: influenza, HIV drugs enlisted to fight SARS. JAMA. 2003; 290:1695-1696.

54. Cao B, Wang Y, Wen D, Liu W, Wang J, Fan G. A trial of lopinavir-ritonavir in adults hospi-talized with severe Covid-19. N Engl J Med. 2020; 382:1787-99.

55. Bryant A, Lawrie AT, Dowswell T, Fordham JE, Mitchell S, Hill RS, et al. Ivermectin for Prevention and Treatment of COVID-19 Infection: A Systematic Review, Meta-analysis, and Trial Sequential Analysis to Inform Clinical Guidelines. Am J Ther. 2021; 28(4):e434-60.

56. Villar J, Ferrando C, Martínez D, Ambrós A, Muñoz T, Soler JA. Dexamethasone treatment for the acute respiratory distress syndrome: a multi- centre, randomised controlled trial. Lancet Respir Med. 2020; 8:267-76.

57. Duan K, Liu B, Li C, Zhang H, Yu T, Qu J, et al. Effectiveness of convalescent plasma therapy in severe COVID-19 patients. Proc Natl Acad Sci USA. 2020; 117(17):9490-6.

58. Shen C, Wang Z, Zhao F, Yang Y, Li J, Yuan J, et al. Treatment of 5 critically ill patients with COVID-19 with convalescent plasma. JAMA. 2020;323(16):1582-9.

59. Rajendran K, Krishnasamy N, Rangarajan J, Rathinam J, Natarajan $\mathrm{M}$, Ramachandran A. Convalescent plasma transfusion for the treatment of COVID-19: systematic review. J Med Virol. 2020; 1-9.

60. Adhikari SP, Meng S, Wu YJ, Mao YP, Ye RX, Wang QZ et al. Epidemiology, causes, clinical manifestation and diagnosis, prevention and control of coronavirus disease (COVID-19) dur-ing the early outbreak period: a scoping review. Infectious diseases of poverty. $2020 ; 9(1): 1-2$. 